School of Finance

University of St.Gallen

ILLUMINATING THE DARK SIDE OF FINANCIAL

INNOVATION: THE ROLE OF INVESTOR INFORMATION

MANUEl AMMANN

MARC ARNOLD

SIMON STRAUMANN

Working PAPERS ON FinANCE No. 2017/04

SWISS INSTITUTE OF BANKING AND FINANCE (S/BF - HSG)

MARCH 2017

THIS VERSION: JUNE 2017 


\title{
Illuminating the Dark Side of Financial Innovation: The Role of Investor Information
}

\author{
Manuel Ammann, Marc Arnold, and Simon Straumann*
}

June 1, 2017

\begin{abstract}
This paper investigates the impact of investor information on financial innovation. We identify specific channels through which issuers of financially engineered products exploit retail investors by using their privileged access to information. Our results imply that imperfect investor information regarding volatility and dividends is crucial to explain the pricing and design of financially engineered products. We confirm our conjecture by exploiting a discontinuity in issuers' informational advantage. The insights are of systemic importance because they suggest that product issuers' behavior in the financial innovation market aggravates investor information problems of the financial system.
\end{abstract}

JEL-Code: D8, G34, M52

Keywords: Structured products, investor information, financial innovation

* We thank Anastasia Kartasheva, Allaudeen Hameed, Jens Jackwerth, Luigi Guiso, Marcel Fischer, Markku Kaustia, Martin Brown, Samuli Knüpfer, Nicolas Kube, Matthias Pelster, Nic Schaub, Yakov Amihud, participants of the Topics in Finance Workshop in Davos, Helsinki Finance Summit on Investor Behavior, Brown Bag Seminar in St.Gallen, German Finance Association Conference, and Swiss Society for Financial Market Research Conference for helpful comments. We also thank Derivative Partners for providing the structured products database and the "Vereinigung zur Förderung des Schweizerischen Instituts für Banken und Finanzen der Universität St.Gallen- HSG" for funding. 


\section{Introduction}

Financial innovations offer tax, liquidity, or other benefits to investors. The dark side is that issuers exploit investors by overpricing these products. Potential reasons behind the dark side are investors' bounded rationality, limited financial literacy, informational disadvantage, or product complexity (Célérier and Vallée, forthcoming; Henderson and Pearson, 2011). The information friction has attracted attention since the 2007-2008 credit crisis because imperfect information in financial innovations can cause trading collapse or market disruptions (Gennaioli, Shleifer, and Vishny, 2012; Hanson and Sunderam, 2013). To mitigate investor exploitation and strengthen financial system resilience it is, therefore, important to understand the role of this friction. Yet, the channels through which imperfect investor information emerges in financial innovations are unclear because information sets of investors and product issuers are usually not observable.

In this paper, we investigate the impact of imperfect investor information on the pricing and design of structured products. We overcome the observability challenge through our access to a large database containing information provided to structured product investors. Our analysis provides two primary results. First, issuers exploit their informational advantage over investors to push overpriced securities to retail investors. We identify specific information channels of this exploitation, namely volatility and dividends. In sharp contrast to standard proxies for the production cost of structured products, market environment, and liquidity which are mostly insignificant, both information channels are economically important determinants of issue pricing. Second, issuers design products to augment their informational advantage. The design result is of systemic importance because it underpins the concern that financial engineering aggravates the imperfect investor information friction in financial markets.

Structured products represent an ideal laboratory to explore the role of imperfect information because they are frequently issued to retail investors with inferior information than financial intermediaries (Bhattacharya, Hackethal, Kaesler, Loos, and Meyer, 2012). In addition, their flexibility in terms of payoff design allows us to analyze the impact of issuers' informational advantage on product structures.

We have access to a large database containing term sheets of all structured products on single stock underlyings issued in Switzerland. Issuers are obliged to disclose important product information to investors in term sheets. Comparing term sheet information available to investors to the (costly) financial information available to product issuers 
from EUREX and IBES allows us to measure the informational gap between issuers and investors. From the term sheets, we also calculate the difference between product issue prices to retail investors and replication prices for identical payout profiles to institutional investors. We label this difference issue premium (IP). It measures the premium at which issuers sell products to retail investors. Analyzing price differences helps us to isolate the impact of the informational gap. Any unobserved price determinant that is correlated with our informational proxies should affect both prices, but not their difference.

We first examine product issuers' exploitation of their volatility information advantage. Whereas issuers have access to implied volatility estimates of a product's underlying, term sheets do not disclose this information. Instead, retail investors tend to rely on historical price discovery (Daniel, Hirshleifer, and Teoh, 2002; Sirri and Tufano, 1998), which is commonly provided in term sheets. We find that issuers earn a $30 \%$ larger IP with products that have a higher implied than historical volatility. As replication prices in our sample decline with implied volatility, this relation suggests that issuers earn higher premiums when investors overvalue a product based on their historical information. We present a battery of refinements to confirm that issuers exploit their volatility information advantage. First, the effect is stronger for products that are more value sensitive to volatility information and have a higher portion of retail investors. Second, products with higher implied than historical volatility tend to have a relatively small implied volatility. Thus, the result is not simply a consequence of investors' being unable to recognize that higher implied volatility should reduces product prices (Henderson and Pearson, 2011). Third, issuers also select underlying stocks with a larger implied relative to historical volatility when designing their products.

We then analyze issuers' dividend information exploitation. Product values in our sample decline with expected dividends because investors are long in the underlying stock and do not obtain dividends that accrue up to maturity. Whereas issuers have access to dividend estimates, term sheets do not disclose this information. The dividend results mirror our conjecture from the volatility analysis. Issuers earn an over $40 \%$ larger premium with products for which analysts forecast a higher future underlying dividend than the publicly available historical dividend. We also find that issuers' tendency to exploit this channel is stronger when product value sensitivity to dividends and the portion of retail investors are larger. In addition, issuers select underlying stocks with a higher forecasted than historical dividend. 
Although we take care to consider price differentials, relevant controls, robustness tests, and refinements to exclude alternative explanations of our results, the challenge in making a causal claim between imperfect investor information and security issuance behavior is the difficulty of isolating differences in issuers' informational advantage independent of observable and unobservable product, macroeconomic, competition, or issuer characteristics. We address this identification problem by exploring a discontinuity in issuers' informational advantage regarding the timing of underlying dividends. Specifically, structured products' payoff is defined on the stock price at maturity and investors are not entitled to receive the underlying's dividend. Thus, investors overvalue a product if they expect the share price at maturity to still trade cum-dividend but it already trades ex-dividend. This overvaluation due to the misjudgment of the dividend payment date can only occur with products that have an ex-dividend date shortly before maturity (just-before products), but not for those that have the ex-dividend date right after maturity (just-after products).1 Therefore, issuers are solely able to exploit superior dividend timing information with just-before products. We explore this discontinuity in issuers' informational advantage around future ex-dividend dates using a standard Regression Discontinuity Design (RDD). We find that whereas just-before products have very similar observable characteristics as just-after products, the former are discontinuously more overpriced than just-after products. This result confirms that issuers use their informational advantage to push overpriced securities to investors.

Our results relate to different streams of the literature. First, several studies analyze investors' misjudgment in the financial innovation market due to product complexity, ignorance of fees, obfuscation, or lack of sophistication (DeMarzo, 2005; Coval, Jurek, and Stafford, 2009; Choi, Laibson, and Madrian, 2009; Carlin, 2009; Carlin and Manso, 2011; Célérier and Vallée, forthcoming). We contribute to this literature by identifying investors' inferior access to information as an important reason for their misjudgment.

Second, we speak to the literature that recognizes imperfect investor information as an important friction in the financial innovation market Ashcraft and Schuermann, 2008; An, Deng, and Stuart, 2011). Gennaioli, Shleifer, and Vishny (2012), Gorton and Metrick (2012), Stein (2012), and Hanson and Sunderam (2013) argue that this friction is crucial to the entire financial system as it can cause large market disruptions when new

\footnotetext{
${ }^{1}$ In case just-after product investors expect the ex-dividend date earlier than the true date, their misjudgment could even induce them to undervalue a structured product.
} 
information arrives. Nevertheless, surprisingly little is known about the channels behind imperfect investor information. An exception is the study of Piskorski, Seru, and Witkin (2015) disclosing significant asset quality misrepresentation by issuers of residential Mortgage-Backed Securities. We contribute to this literature by identifying volatility and dividends as two important channels behind investors' information lack. A thorough understanding of the channels is essential to define appropriate policy measures that mitigate this friction. In addition, our results on the design of structured products emphasize the systemic stability concern. Specifically, they imply that financial innovators deliberately structure products for which investors have inferior information.

Third, we complement studies on the pricing of structured products. According to this literature, it is challenging to explain the variation of structured products' IP. Henderson and Pearson (2011) analyze the mispricing of 64 retail structured products. Out of nine potential explanatory variables, only one (implied volatility of the underlying) is significantly associated with IPs. Benet, Giannetti, and Pissaris (2006) also find a substantial IP. They show that both the underlying's implied volatility and product maturity play a role. Wallmeier and Diethelm (2009) demonstrate that investors overpay structured products, particularly if their coupon payments are large. Rieger (2012) and Hens and Rieger (2014) argue that investors overvalue structured products because they assign wrong probabilities to some future scenarios. Finally, Wilkens, Erner, and Röder (2003) and Stoimenov and Wilkens (2005) investigate secondary market prices of structured products. We contribute by illustrating that imperfect investor information is an economically important pricing determinant.

\section{Structured product data sample}

This section provides an introduction to the market for structured products and presents our data sample.

\subsection{The market for structured products}

Structured products are investment instruments with a payoff that is linked to the performance of one or several underlyings from a wide range of asset classes such as equity, fixed-income, and commodities. They are composed of multiple financial instruments, commonly a combination of bonds, equities and derivatives. Issuers can tailor structured 
product to the need of investors. The flexible product design, however, also allows issuers to mitigate competition by impeding comparability with products of competitors. Most structured products refer to equity underlyings both in the US and in Europe (Bloomberg Brief: Structured Notes, 2015; Structured Retail Products, 2015). Structured products are issued on the primary market and subsequently traded on the secondary market until they expire. In this study, we focus on the primary market for two reasons. First, the secondary market is relatively illiquid and has a much lower traded volume than the issue volume on the primary market (SVSP, Schweizerischer Verband für Strukturierte Produkte, 2013). Second, we are not only interested in issuers' pricing decision but also in the design of products. The product structure, however, is determined at issue.

The market for structured products has grown substantially. As of December 2012, Bouveret, Crisóstomo, Gentile, Mendes, Pereira da Silva, and Silva (2013) report a total outstanding volume of structured products in Europe of almost EUR 770bn. This notional volume amounts to about $4 \%$ of household financial wealth, or $12 \%$ of mutual funds' asset under management in the European market. Also the US market has steadily increased its share in the global market for structured products. In 2014, the US volume sales account for more than USD 41bn. This amount corresponds to about $40 \%$ of the new net cash flows to the US mutual funds industry in the same year. In 2012, the portion was only $20 \%$ (Investment Company Institute, 2015).

In this study, we focus on a large database of structured products issued in the Swiss market. Banks in this market rely on standardized product categories, which is important for the systematic collection of comparable products (Structured Retail Products, 2015). With a total sales volume of USD 21.3bn, Switzerland is the second largest European issuer of structured products in 2014 (Structured Retail Products, 2015). The Swiss market is also global leader in terms of structured products volume invested in custody accounts (Swiss Bankers Association, 2011). Swiss banks heavily engage in the US market. The two largest banks in Switzerland, Credit Suisse and UBS, hold a combined market share of almost $20 \%$ of the volume of all structured products issued in the US during 2014 (Bloomberg Brief: Structured Notes, 2015).

\subsection{Data sample}

Our main database is provided by Derivative Partners. It contains term sheets of all structured products on equity underlyings issued in Switzerland between January 2005 
and December 2010. The database, which is also used in Arnold, Schuette, and Wagner (2016), comprises 15'170 publicly issued products that target the retail market $\mathrm{I}^{2}$

From this database, we exclude products on multiple underlyings (14'138) and with missing data (20), leaving us with a total sample of 1012 structured products on a single equity underlying. We focus on products with a single equity underlying because they can be replicated from observed market prices of interest rates and EUREX options 3 . The availability of market prices is important to investigate the difference between structured product prices to retail investors and replication (market) prices to institutional investors. Our sample of priced products is considerably larger than in existing studies. For example, Benet, Giannetti, and Pissaris (2006) investigate 31 structured products, and Henderson and Pearson (2011) consider 64.

Table1 1 reports the number of launched products grouped by issuer, product category, and year. The products were issued by two Swiss banks and 5 international banks in Switzerland. Together, the two Swiss banks, Credit Suisse and UBS, account for more than two third of our sample. Goldman Sachs and Royal Bank of Scotland issue a share of $14.3 \%$ and $13.2 \%$, respectively. The sample contains six different product categories with 87 unique underlyings. Discount Certificates, Barrier Reverse Convertibles, and Bonus Certificates are the most prevalent categories. From 2005-2008, the number of issued structured products increased each year, whereas it declined between 2008 and 2010.

\section{INSERT TABLE 1 NEAR HERE}

Product payoff profiles are defined in the term sheets. On the initial fixing date, the issuing bank defines the terms of a structured product such as the issue price, strikes, coupon payments, barrier level, redemption, and all relevant dates. These terms are communicated to the investor in the final term sheet of a product. Although Derivative Partners provides a database which lists all final term sheet items of every structured product, we manually double check each database entry with the corresponding term sheet. Product categories in our sample have the following profiles:

With a Discount Certificate, the investor purchases an underlying stock at a discount but resigns the upside stock performance beyond a prespecified cap. If the stock closes

\footnotetext{
${ }^{2}$ Above a minimum investment threshold around CHF 25’000, most issuers in the Swiss market offer individual structuring of products on behalf of clients. These tailor-made products are issued privately and, hence, not included in the database.

${ }^{3}$ EUREX options data is provided by the FMI department of the Karlsruhe Institute for Technology.
} 
above this cap at maturity, the investor obtains a payoff equal to the difference between the initial stock and the strike prices. Otherwise, he receives the stock performance.

Barrier Discount Certificates likewise embed a discount feature that allows the investor to buy the underlying stock below its market price. The barrier feature provides conditional capital protection. The investor receives a prespecified payoff if the stock never touches the lower barrier during the product's lifetime. If this barrier is touched, the capital protection is cancelled and the product converts into a Discount Certificate.

Reverse Convertibles have the same payoff profile as Discount Certificates. The only difference is that Reverse Convertibles also pay coupons and have a nominal amount.

Capped Outperformance Certificates allow the investor to participate disproportionately in the performance of the underlying stock above the strike price. If the stock closes below this strike at maturity, the product has the same payoff structure as the stock. Above the strike, the investor obtains a multiple of the difference between the stock and strike prices up to a predetermined cap.

Barrier Reverse Convertibles pay a fixed coupon and are capital protected as long as the underlying stock does not touch a prespecified lower barrier during the product's lifetime. If the barrier is touched, the capital protection is canceled and a Barrier Reverse Convertible converts into a Reverse Convertible.

Bonus Certificates allow the investor to participate in the underlying stock with a down-side protection at a fixed bonus level as long as the stock does not touch a prespecified lower barrier during their lifetime. Once the barrier is touched, the down-side protection is canceled and the Bonus Certificate simply follows the stock performance.

In contrast to a direct investment in the underlying stock, the investor is not entitled to receive the stock's dividend payments. This applies to all product categories.

\section{Product pricing and imperfect information}

In this section, we investigate the impact of imperfect information on issuers' premium from launching structured products.

\subsection{Dependent variable: Issue premium}

We use the issue premium (IP) of structured products as our dependent variable. The issue premium is the percentage difference between the issue price and the replication 
price of a structured product (Henderson and Pearson, 2011):

$$
I P=\frac{\text { Issue Price }- \text { Replication Price }}{\text { Issue Price }}
$$

The issue price is the initial price at which banks sell a structured product to retail investors. Due to their access to fixed income and option markets, institutional investors can replicate the payoff profile of a structured product with traded instruments. Thus, the replication price is the market price to institutional investors of replicating a product's payoff profile. Intuitively, the IP is the percentage difference between prices to retail and institutional investors of the same payout profile at the same time. As a product issuer can hedge his future obligation to the retail investor when selling a structured product by simply replicating the payoff profile, the IP reflects the issuer's profit of launching a product 4 . In addition, the IP captures issuance fees and commissions

Whereas product term sheets provide us with issue prices, we need to calculate replication prices. First, we determine the fixed income and option components that replicate a structured product. Second, we derive the price of each component from observed market prices. Finally, the replication price of a structured product is the sum of the prices of the components that replicate its payoff profile. The Appendix illustrates the derivation of replication prices in detail.

We do not incorporate issuance fees or commissions into our calculation of the issue premium. Whereas they affect the gross issue premium, fees and commissions are standardized and fixed across product categories such that they are unlikely to be systematically correlated with the informational advantage of issuers.

\subsection{Explanatory variables and hypotheses}

Term sheets disclose most parameters relevant to assess the value of a structured product. Thus, it is relatively easy even for less financially sophisticated retail investors to compare term sheet information between different products. For instance, a product with a higher coupon seems more attractive than a product with a lower coupon but otherwise identical term sheet information. It is, however, more challenging for retail investors to compare products along dimensions that are not exposed in term sheets. Therefore, we argue that it is easier for issuers to sell structured products to retail investors that are overpriced in

\footnotetext{
${ }^{4}$ We control for additional factors affecting hedging costs in our analysis.
} 
terms of product characteristics which are not observable in term sheets. Two important replication price determinants of structured products on which there is no information in term sheets are the underlying's implied volatility and expected dividend.

We define implied volatility (Impl Vola) as the annualized implied volatility of an atthe-money put option on the product's underlying with a maturity equal to the product's maturity based on the approach outlined in the Appendix. Impl Vola is available to product issuers through, for example, EUREX or BLOOMBERG. It is difficult for retail investors to obtain implied volatility estimates to value a structured product because access to traded options data is restricted and costly, e.g., a one-year access to BLOOMBERG's proprietary computer system is charged around $\$ 25,000$ per user. Thus, retail investors have to resort to readily available but more heuristic volatility measures. As suggested by the literature (Daniel, Hirshleifer, and Teoh, 2002; Sirri and Tufano, 1998), they tend to rely on historical information. In addition, structured product term sheets often contain a picture of the historical price evolution over previous years. Therefore, we incorporate the historical volatility of a product's underlying to capture the volatility estimate available to retail investors. Historical volatility (Hist Vola) is calculated as the standard deviation of a product underlying's returns over the 255 trading days before the initial fixing date. We choose 255 days because it corresponds to the median product maturity in our sample.

Hist Vola can diverge from the Impl Vola available to issuers. Because replication prices of all products in our sample decline with volatility, issuers can exploit this divergence if retail investors underestimate volatility and, hence, overestimate a product's value. Thus, an Impl Vola larger than Hist Vola, which we capture with a dummy equal to one (Higher Vola), constitutes a volatility information advantage for a structured product issuer. Our first hypothesis is that issuers demand larger premiums for products over which they have a volatility information advantage.

Expected dividends of a product's underlying are a second crucial pricing factor, which is not provided in product term sheets. Product issuers usually have access to dividend forecasts such as IBES. We capture the dividend information of issuers (IBES Div Yield) as the ratio between the present value of expected dividend payments based on IBES forecasts that occur during the lifetime of a product and the stock price of the underlying at the initial fixing date.

Dividend forecasts are restricted and costly. Retail investors can instead resort to 
historical dividend information, which is publicly available in the Internet, to estimate expected dividends. We capture this information by Hist Dividend Yield that is the ratio between the present value of expected dividend payments based on historical dividends in the 255 days prior to the initial fixing date and the underlying's stock price at the initial fixing date. We consider 255 days because this lifetime equals the median product maturity in our sample.

Structured product investors are usually not entitled to receive dividend payments because they only hold derivative positions on the underlying. Since the value of all products in our sample is positively related to the stock price of the underlying (all products exhibit a delta that is strictly larger than zero), a higher future dividend payment during the lifetime of a structured product ceteris paribus reduces the product's current replication price. Thus, an investor overvalues a structured product if he underestimates future dividends. We proxy this dividend information advantage of the issuer with a dummy (Higher Div) that is equal to one if IBES Dividend Yield is larger than Hist Dividend Yield, and zero otherwise. Our second hypothesis is that issuers demand larger premium for products over which they have a dividend information advantage.

\subsection{Control variables}

We incorporate the standard control variables of Henderson and Pearson (2011) into our analysis. Excess Return Underlying is calculated as the return of the 3 and 12 months continuous annual returns of the underlying in excess of the 3 and 12 months continuous annual returns of the Swiss Market Index (SMI), respectively. Log Market Capitalization is the natural logarithm of the market value of equity of the underlying (in USDbn) at the initial fixing date, and Turnover Underlying the natural logarithm of the dollar value (in USDm) of the cumulated trading volume of the underlying during 1 and 3 months prior to the initial fixing date, respectively. 20d Call Volume and 20d Put Volume are the cumulated trading volumes of EUREX call (put) options written on the underlying during the 20 trading days preceding the initial fixing date of a structured product divided by the volume of call (put) options written on all underlyings during the same time period. We obtain Delta (Vega) as a product's first order derivative with respect to the price (volatility) of the underlying using the Black-Scholes formula, scaled by the product's denomination. Delta (Vega) of products with barrier options is calculated numerically. Average Trading Size is the logarithm of the average trading size of a structured product 
in USD on the secondary market. All data on underlyings is from Datastream, on option components from the EUREX database, and on dividend consensus estimates from IBES.

\subsection{Descriptive statistics}

Descriptive statistics are presented in Table2, The average issue premium in our sample is $1.48 \%$. This magnitude coincides with the average issue premium in empirical samples of similar simple short term structured products (Burth, Kraus, and Wohlwend, 2001; Baule, Entrop, and Wilkens, 2008; Célérier and Vallée, forthcoming). Outside of Switzerland, issue premiums tend to be larger. The studies of Stoimenov and Wilkens (2005) for the German market and of Henderson and Pearson (2011) for the US market find average issue premiums of $3.89 \%$ and more than $8 \%$, respectively. The average implied and historical volatilities are $0.29 \%$ and $0.31 \%$, respectively. Whereas they are of similar average magnitude, historical volatility has a larger standard deviation. 563 of the 1012 products in our sample have a Higher Vola dummy of one. IBES Dividend Yield and Hist Dividend Yield have similar means and quantiles. Both dividend measures are characterized by a relatively low standard deviation. For 608 of the 1012 products in our sample, Higher Div is equal to one. The correlation between Higher Vola and Higher Div is 0.08 . Thus, the two dummy variables mainly identify two distinct product groups.

\section{INSERT TABLE 2 NEAR HERE}

The Vega of all our products is negative, which implies that investors are always short volatility. The Delta of sample products is strictly positive. Thus, investors benefit from underlying price increases or dividend reductions during the products' lifetime. On average, products have a time to maturity of 294 trading days.

\subsection{Empirical approach}

We start by investigating the issue pricing of structured products. To this end, we run cross-sectional OLS regressions of IP on our explanatory and control variables. Our main analysis is based on the following regression model:

$$
I P_{i}=\alpha+\beta_{1} \text { Higher Dummy } y_{i}+\beta_{j} \text { Controls }_{i j}+\epsilon_{i} .
$$

$I P_{i}$ is the IP of product $i$. It corresponds to the percentage difference between the 
prices to retail and institutional investors for the same payout profile at the same time. Higher Dummy represents our information advantage proxy, which is the Higher Vola dummy for volatility and the Higher Div for dividends. Controls $s_{i j}$ is a vector of the control variables of Section 3.3. In addition, we include year fixed effects in all regressions to control for aggregate trends such as in product demand. We use different specifications and refinements of the basic regression model to reinforce our hypotheses.

\subsection{Volatility results}

In Column (1) of Table 3, we replicate the setting of Henderson and Pearson (2011) and find that our results are consistent with their study. Whereas Impl Vola is positively associated with IPs, the remaining controls are either insignificant or not robust to alternative controls (see Columns (2)-(6)).

\section{INSERT TABLE 3 NEAR HERE}

In Column (2), we add historical volatility (Hist Vola) and the Higher Vola dummy. The coefficient on Hist Vola suggests that issuers reduce IP with historical volatility. In addition, the coefficient on Higher Vola implies that issuers demand a $0.542 \%$ larger IP for products with a higher implied than historical volatility. This magnitude is important, accounting for more than one third of average IPs. These results provide a first indication that issuers collect higher IPs if they have a volatility information advantage, i.e., if retail investors underestimate volatility based on their historical information. A caveat with our Higher Vola dummy is that it could be correlated with a volatility risk premium. Whereas this premium affects option prices (e.g., Carr and $\mathrm{Wu}, 2016$ ), the advantage of using IP in our regressions is that the IP corresponds to the difference between prices to retail and institutional investors. Thus, even if the volatility risk premium affects option prices, it should not drive the price difference of the same option to different investors.

We also calculate the average Impl Vola of products that have a Higher Vola dummy equal to one. Their average Impl Vola $(0.265 \%)$ is significantly smaller than that of products with a Higher Vola dummy of zero $(0.314 \%)$. Thus, issuers increase the price of products not simply when Impl Vola is large, but also when Impl Vola is relatively small yet larger than the historical volatility. Therefore, imperfect information seems to play a role besides the financial literacy explanation in Henderson and Pearson (2011) that retail investors are simply unaware of the impact of volatility on structured products. 
To investigate whether the quantitative magnitude of the Higher Vola coefficient is consistent with our information exploitation story, we first calculate the difference between the implied and historical volatilities for all products with Higher Vola equal to one. The approximate value of a product's informational advantage for an issuer is then retrieved by multiplying this difference with the product Vega. Intuitively, this value is a retail investor's percentage overvaluation of a product if he relies on the historical instead of the implied volatility. Issuers' average informational advantage value across all products with a dummy equal to one is $1.86 \%$. Thus, the coefficient of Higher Vola in Column (2) suggests that issuers are, on average, able to exploit approximately $30 \%$ of their informational advantage. The economic magnitude of this exploitation is plausible given that approximately half of products are sold to retail investors in Switzerland (SVSP, Schweizerischer Verband für Strukturierte Produkte, 2013) and that Hist Vola is only a proxy of issuers' volatility informational advantage.

A possible caveat with our results in Column (2) is multicollinearity. Hence, we consider the continuous interaction between historical and implied volatilities in Column (3) and standardize Impl Vola, Hist Vola, and their interaction term. 5 The significantly negative coefficient of this interaction confirms that banks particularly demand a larger IP for products with high implied volatility when historical volatility is low.

We now present several refinements to support our first hypothesis that issuers exploit imperfect volatility information.

If exploitation of imperfect volatility information drives our results, then the coefficient on Higher Vola should be more pronounced for products with a more negative Vega. For such products, investors particularly overestimate product values when they underestimate volatility. Indeed, the coefficient on the interaction Higher Vola $x$ Vega in Column (4) shows that if Vega is more negative, the impact of Higher Vola on IPs is stronger.

The literature finds a negative relation between trading size and investor sophistication (Battalio and Mendenhall, 2005; Bhattacharya, Black, Christensen, and Mergenthaler, 2007; Bhattacharya, 2001). Thus, we calculate the average trading size of each structured product on the secondary market (Average Trading Size) and use this variable in Column (5) as a proxy of the sophistication of a certain product's investors. The

\footnotetext{
${ }^{5}$ For all regressions in each column, we test for multicollinearity using Variance Inflation Factors (VIF). Only the interaction term between Impl Vola and Hist Vola exhibits a critical VIF.
} 
interaction between Higher Vola and Average Trading Size has a significantly negative coefficient. This result supports our imperfect information exploitation hypothesis because it implies that issuers particularly use their informational advantage to increase the price of securities when investor sophistication is low.

Following the idea of Célérier and Vallée (forthcoming) that complexity drives IPs, we also incorporate a proxy of complexity in Column (6). We define complexity as the number of different features contained in a product (Features). Each strike, barrier, or the presence of coupon payments adds one additional feature to a structured product. The idea behind this proxy is that the valuation of products that consist of more features is more complex. The result in Column (6) confirms the positive relation between complexity and IP in Célérier and Vallée (forthcoming). However, the coefficient of Higher Vola is hardly affected by this additional control. This finding suggests that issuers' informational advantage is a driver of IPs besides product complexity.

\subsection{Dividends results}

We now test whether product issuers exploit their informational advantage regarding dividends. The results are presented in Table 4. In the first column, we include IBES Div Yield as a measure of forecasted dividend payments. The significantly positive coefficient of IBES Div Yield shows that an increase in expected dividend yield raises IP. The magnitude of the coefficient implies that increasing IBES Div Yield by one standard deviation (0.022) enhances IP by $0.15 \%$.

\section{INSERT TABLE 4 NEAR HERE}

We incorporate our proxy of retail investors' information on dividends in Column (2). The significantly negative coefficient of Hist Div Yield suggests that IPs are lower if historical dividends are higher. In addition, products with Higher Div equal to one carry an IP that is on average $0.616 \%$ larger. This effect is economically important because it corresponds to an increase of more than $40 \%$ of the average IP. These results provide a first indication for our second hypothesis that issuers collect higher IPs if they have a dividend information advantage over retail investors.

To investigate whether the quantitative magnitude of the Higher Div coefficient is consistent with our information exploitation story, we first calculate the difference between the present values of expected IBES dividends and historical dividends over the lifetime 
of all products with Higher Div equal to one. We then obtain the approximate value of a product's informational advantage for an issuer by multiplying this difference with the product delta. Intuitively, this value is a retail investor's percentage overvaluation of a product if he relies on historical instead of forecasted dividends. Issuers' average informational advantage value across all products with a dummy equal to one is $1.43 \%$. Thus, the coefficient of Higher Div in Column (2) suggests that issuers are, on average, able to exploit around $43 \%$ of their informational advantage. The economic magnitude of this exploitation is plausible given that approximately half of products are sold to retail investors in Switzerland (SVSP, Schweizerischer Verband für Strukturierte Produkte, 2013 ) and that Higher Div is only a proxy of issuers' informational advantage.

A possible caveat with our results in Column (2) is multicollinearity. Hence, we consider the continuous interaction between IBES Div Yield and Hist Dividend Yield in Column (3), and standardize these variables. The significantly negative coefficient of the interaction term confirms our conjecture that issuers demand a higher IP with larger expected dividends particularly if historical dividends are small.

We now present several refinements to support our second hypothesis that issuers exploit imperfect dividend information.

In Column (4), we include the interaction between Higher Div and Delta. If Delta is larger, underestimating dividends has a stronger impact on retail investors' perceived product value. The significantly positive coefficient of this interaction suggests that our dividend information exploitation result is more pronounced for products with higher sensitivity to this information. This finding supports our imperfect dividend information exploitation hypothesis.

Column (5) shows that the interaction between Higher Div and Average Trading Size has a significantly negative coefficient. This result supports the information exploitation hypothesis because it implies that issuers particularly use their dividend information advantage to overprice securities when investor sophistication is low. Finally, the last column confirms that the coefficient of Higher Div is not driven by complexity. 


\section{A regression discontinuity design for dividend pay- ments around the maturity date}

Product issuers have privileged access to dividend timing information compared with retail investors. For example, they can rely on internal and external analyst forecasts, or on timing information from market makers' order books (Chae, 2005). In addition, some retail investors lack information on the impact of this timing on structured product payoffs. For instance, the ex-dividend date is relevant for this payoff and not the dividend announcement, payment, or record date. In this section, we exploit a discontinuity in issuers' dividend timing information advantage to support our second hypothesis.

\subsection{Intuition}

A structured product investor is not entitled to receive the underlying's dividend that accrues during the lifetime of a product, i.e., product payoffs are defined on the underlying's ex-dividend price. A discrete dividend before product maturity then reduces the investor's final payoff of a structured product. Thus, even a minor misjudgement of future ex-dividend dates can have a large impact on perceived product values. Specifically, if a retail investor misjudges the ex-dividend date after product maturity but the underlying actually goes ex-dividend before or at maturity, he obtains the product payoff based on the ex-dividend share price instead of cum-dividend $]^{6}$ Therefore, retail investors may overvalue a product if they have incomplete dividend timing information and the future ex-dividend date occurs shortly before product maturity (just-before products). This overvaluation cannot occur if the future ex-dividend date occurs shortly after product maturity (just-after products). In this case, investors would undervalue a structured product if they misjudge the ex-dividend date to occur before product maturity 7$]$ Thus, issuers can only use their informational advantage on dividend timing to push overvalued securities to investors with just-before products but not with just-after products.

This discontinuity of issuers' informational advantage at product maturity is quantitatively important for product IPs. For instance, consider a product A with a maturity of one year, one discrete dividend payment of $1.5 \%$, an ex-dividend date one day after

\footnotetext{
${ }^{6} \mathrm{~A}$ share starts trading ex-dividend in the opening of an ex-dividend date, but a structured product matures at closing.

${ }^{7}$ If investors misjudge the ex-dividend date to occur after the future ex-dividend date, this misjudgment would have no impact on their product valuation as both dates occur after product maturity.
} 
maturity, a Delta of one, and an IP equal to our sample's average of $1.48 \%$. An otherwise identical product $\mathrm{B}$ with a maturity that is just one day shorter than that of product A has an around $1.5 \%$ lower replication price (ignoring discounting). Thus, if retail investors misjudge the future dividend date of product $\mathrm{B}$ to be one or more days later, such that they are ready to pay the same issue price as for product A, product B's IP doubles to $1.48 \%+1.5 \%=2.98 \%$ compared with product's A IP of $1.48 \%$. Whereas issuers double their proceeds with product $\mathrm{B}$, however, investors attain a less attractive product. Specifically, the $1.5 \%$ lower replication price of product B implies that, on average, investors attain a $1.5 \%$ smaller investment performance with product $B$ than with product $\mathrm{A}$.

\subsection{RD approach and results}

We now exploit the discontinuity in issuers' informational advantage regarding dividend timing information around product maturity dates to investigate the impact of imperfect information on an outcome variable that captures product performance. To this end, we closely follow the standard regression discontinuity (RD) approach in Chang, Hong, and Liskovich (2014).

We define our assignment variable as the difference between the closest expected exdividend date and the product maturity date expressed in days. The closest expected ex-dividend date is the product underlying's expected ex-dividend date nearest to product maturity. We estimate expected ex-dividend dates as the historical ex-dividend dates in the year prior to the initial fixing date of a product. 8 A negative (positive) value of the assignment variable indicates that the expected ex-dividend date occurs before (after) the maturity date. A product with a negative or zero assignment variable (just-before product) is treated because issuers have an exploitable informational advantage with respect to dividend timing. A product with a positive assignment variable is non-treated (just-after product). We expect that treated products are more overpriced compared to non-treated products.

We use the unexplained product performance (UP) as a measure of structured products' initial overpricing to retail investors. The outcome variable UP is the fraction of a product's ex-post performance that is not explained by the performance of its underly-

\footnotetext{
${ }^{8}$ Ex-dividend dates are usually relatively stable. The mean deviation from the previous year's date in our sample is only seven days.
} 
ing. We use UP as an overpricing measure because higher overpricing, i.e., larger issue premiums (IPs), leads to inferior unexplained product performance for investors. In our main analysis, we do not directly use IP as the outcome variable. The calculation of IPs is based on replication prices that depend on our own dividend date projections. Thus, minor dividend date projection errors could lead to a spurious correlation between treatment assignment and the outcome variable IP. Such errors may even cause discontinuities in the outcome variable around the threshold and, hence, drive our results from the RD design. In contrast, UP is independent of how we calculate initial replication prices and, thus, cannot exhibit a discontinuity around the threshold due to our projection errors. Hence, we proceed by using UP in the RD design 9

To obtain UPs, we collect the residuals of the regression

$$
\begin{aligned}
& \text { Product Performance }_{i}=\alpha+\beta_{1} \text { Return Underlying }_{i}+ \\
& \beta_{2} \text { Product Category }_{i}+\beta_{3} \text { Return Underlying } \text { R Product Category }_{i}+\epsilon_{i} \text {. }
\end{aligned}
$$

Product Performance is the annualized performance of product $i$ calculated as the return between the issue price and the final payoff and Return Underlying is the annualized total return of the underlying of product $i$ multiplied by delta. Multiplying the underlying return with delta accounts for the property that structured products have differing sensitivities to their underlying. As alternative product categories exhibit diverse payout profiles, we also incorporate Category that captures the product category of product $i$ and its interaction with Return Underlying. We present the regression output in Table 5. With an R-squared of 90\%, the regression model reflects the variation in Product Performance very well. The residuals of Eqn. (3) exhibit a standard deviation 0.093. We use these residuals as our outcome variable UP. A low UP indicates high initial overpricing. UP, however, could also be affected by a misspecification of the pricing model in Eqn. (3). We mitigate this concern in two ways. First, we apply alternative pricing model specifications. Second, we measure the UP differences between treated and non-treated products within the RD approach and, thus, systematic misspecifications should cancel out.

\section{INSERT TABLE 5 NEAR HERE}

\footnotetext{
${ }^{9}$ We repeat the analysis by using IP as the outcome variable in the RD design and obtain similar results.
} 
Figure 1 depicts UPs around the threshold. We fit a linear function on either side of the threshold using binwidths of 5 and 10. Each bin represents the average of either 5 or 10 observations ${ }^{10}$ The discontinuity in UPs at the threshold implies that just-before products have a discontinuously lower unexplained product performance than just-after products.

\section{INSERT FIGURE 1 NEAR HERE}

If the variation in the treatment near the threshold is approximately randomized, just-before and just-after products should only differentiate with respect to issuers' informational advantage. To ensure randomization around the threshold in our application, issuers should not be able to completely manipulate the difference between ex-dividend and maturity dates (McCrary, 2008). We test this randomization condition with the standard manipulation test based on McCrary (2008) and find no discontinuity in the density function of the assignment variable around the threshold (t-statistics of 0.76). Thus, manipulation of the assignment variable is not a concern for our analysis.

In addition to the statistical evidence, we also provide intuitive practical evidence that issuers cannot completely manipulate the assignment variable. Specifically, Figure 2 shows that banks issue structured products throughout the year. Around $80 \%$ of exdividend dates in our sample, however, occur in the dividend season during March, April, or May. Thus, to create just-before products by manipulating their maturities, issuers would have to considerably deviate from standardized maturities $(0.5,1,1.5,2,2.5$ or 3 years) with products issued in June, July, August, December, January, or February. We find, however, that $76 \%$ of products issued in these month have standardized maturities, which is similar to the $70 \%$ of products with standardized maturities issued in March, April, May, August, September, or October.

We also plot products' time to maturity around the RD threshold in Figure 3 . Most products have a maturity of one or just below one year because products with a maturity beyond one year are subject to the stamp tax in Switzerland. Whereas issuers could manipulate the just-after products with a one year maturity on the right-hand side of the threshold to become just-before products by simply increasing their maturity by a few days, such manipulated products would lose their tax advantage. As almost no dots on the right-hand side of the threshold are slightly above the one year maturity line,

\footnotetext{
${ }^{10}$ The number of observations per bin can vary if there is an unusually high or low number of observations on a given day.
} 
Figure 3 implies that issuers abstain from such manipulation. This example shows that exogenous reasons for product maturities such as taxes prevent issuers from completely manipulating the assignment variable.

\section{INSERT FIGURE 2 NEAR HERE}

\section{INSERT FIGURE 3 NEAR HERE}

We now apply a fuzzy RD design to establish a causal relationship between issuers' informational advantage and the degree of product overpricing. We use a fuzzy RD approach because at product initiation, issuers only have estimated future ex-dividend dates but not realized ex-dividend dates and, hence, do not know with certainty whether a product is treated. To explore the discontinuity in issuers' informational advantage around product maturity dates, we use our projected ex-dividend dates as an instrument for the actual ex-post realized ex-dividend dates. Following Chang, Hong, and Liskovich (2014), we employ a two-stage least-squares approach. As we have no prior on the functional relationship between our assignment variable and the outcome variable, we use a local polynomial of order one to construct the point estimator 11

The first-stage regression is as follows:

$$
\text { Ex Post }_{i}=\alpha_{1}+\beta_{1} \text { Days }_{i}+\text { Ex Ante }_{i}\left[\alpha_{2}+\beta_{2} \text { Days }_{i}\right]+\epsilon_{i} .
$$

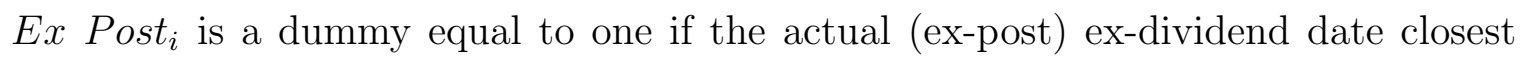
to the maturity date occurred after product maturity and zero otherwise. Days $s_{i}$ is the difference between our projected ex-dividend date closest to the maturity date and the maturity date measured in days. Ex Ante $e_{i}$ is a dummy equal to one if our projected ex-dividend date occurred after product maturity and zero otherwise. We present the regression output in Table 6 .

\section{INSERT TABLE 6 NEAR HERE}

In the second-stage regression, we apply the fitted values from Eqn. (44) as an instrument for ExPost E: $^{2}$

$$
U P_{i}=\alpha_{1}+\beta_{1} \text { Days }_{i}+\widehat{\text { ExPos }_{i}}\left[\alpha_{2}+\beta_{2} \text { Days }_{i}\right]+\epsilon_{i}
$$

\footnotetext{
${ }^{11}$ The results are also robust for local polynomials of order two or higher.
} 
$U P_{i}$ is the outcome variable, $\widehat{E x P O s} t_{i}$ is the predictor for Ex Post $t_{i}$ estimated in Eqn. (4), and $\alpha_{2}$ is the coefficient of discontinuity at the threshold. If issuers push overpriced products to retail investors when their informational advantage is higher, $\alpha_{2}$ should be positive.

The RD design requires the specification of a bandwidth determining the number of observations on either side of the threshold. We follow the rule-of-thumb (ROT) bandwidth calculation presented in Lee and Lemieux (2010). The optimal bandwidths of the UPs requires 86 observations on the left-hand side and 51 observations on the right-hand side of the threshold, respectively. These bandwidths corresponds to a time window of $[-19,19]$ days around the maturity date.

The results of the second-stage regression are presented in Table 7. We find a positive and significant discontinuity in UP of $10.1 \%$ at the threshold between treated and nontreated products with a t-statistics of 2.18. This discrete jump represents 1.1 times the one-standard-deviation change in UPs. According to our RD design, just-before and just-after products should only differentiate in issuers' informational advantage around the threshold. Thus, the upward jump implies that issuers increase the price of products when they have an informational advantage over investors.

Table 7 also reports the coefficients and t-statistics of the second-stage regression for all cut-offs in a six-week time window around our assignment variable threshold of zero. As expected, days around zero are significant. From all remaining cut-offs, only day six exhibits a marginally significant discontinuity. This result confirms that the discontinuity is important only around our threshold.

\section{INSERT TABLE 7 NEAR HERE}

To further verify the RD assumption of local randomization, we investigate whether observable variables also exhibit discontinuities around the threshold. To this end, we repeat our RD approach but replace $U P_{i}$ of Eqn. (5) with the respective variable. A significant jump/drop of alternative variables besides UP at the threshold could raise the concern that the just-before products used in our RD approach differ discontinuously from just-after products in other dimensions than the informational advantage, which could drive our main finding. The results are presented in Table 8. We find no significant discontinuity for most observable variables. Only Delta is marginally significant and positive. This jump, however, tends to reduce UP for just-after products compared with just-before products (see Eqn. 3) and, hence, works against finding a positive dis- 
continuity in UP. Another caveat is that the discontinuity in UP could be driven by a discontinuity in the underlyings' return. We observe, however, no discontinuity for Underlying Return. We further test whether the time to maturity of just-before products deviates more often from standardized time to maturities compared with just-after products. We measure Deviation as the absolute distance between the structured products' time to maturity and the closest standardized time to maturity $(0.5,1,1.5,2$, or 3 years) in years. A negative coefficient would indicate that issuers deviate more often from standardized maturities before than after the threshold to manipulate product maturities, which could impact UPs due to, for example, tax reasons. We find no significant discontinuity.

\section{INSERT TABLE 8 NEAR HERE}

Overall, our RD approach confirms that issuers provide investors with overpriced products particularly when their informational advantage is larger.

\section{Product design and imperfect information}

According to Sections 3.2 and 4 , issuers install a larger IP for products on underlyings with a higher informational advantage. In this section, we examine whether issuers also structure products towards their informational advantage regarding volatility and dividends. To this end, we employ a matched sample approach to compare the informational advantage of underlyings that are chosen for a product to otherwise similar underlyings that are not chosen. This approach allows us to reduce the bias due to confounding variables and, thus, increases the validity of our results.

We proceed as follows. We start by defining the set of underlyings that issuers possibly choose for their structured products. We assume that this available set consists of all underlyings that have ever been chosen by an issuer during our observation period. For each week and underlying in the available set, we calculate Impl Vola, Hist Vola, IBES Div Yield, and Hist Div Yield for a time to maturity of 255 days. We choose 255 days because this corresponds to the median product maturity in our sample. We proxy information advantage with our Higher Vola and Higher Div dummies defined in Section 3.2 .

For each underlying that is actually chosen for a structured product, we then select five underlyings from the available set that are the closest neighbors with respect to the 
square root of the sum of squared distances weighted by the inverse sample covariance (Mahalanobis distance). As matching variables, we use the control variables suggested by Henderson and Pearson (2011), the index of the underlying, and the corresponding industry based on the two-digit Standard Industrial Classification (SIC) code. The majority of products, namely 579 out of the 1012, is issued on underlyings listed in the Swiss Market Index (SMI). 292 products are constructed with underlyings that belong to the EuroStoxx 50 Index. We assign the remaining 141 product underlyings to the category "Other". As launching a product takes some time due to the design, planning, and subscription period, we lag the matching variables by up to three weeks.

Finally, we compute the difference between the value of Higher Vola (Higher Div) of the actually chosen underlying and the average value of Higher Vola (Higher Div) of the matched underlyings. We perform one-sided t-test to analyze whether this difference is significantly larger than zero. Our findings are presented in Table 9.

\section{INSERT TABLE 9 NEAR HERE}

In Column (1) we lag the matching variables by one week. The results show that chosen underlyings have significantly more often Higher Vola and Higher Div dummies equal to one than comparable available underlyings. Quantitatively, the differences imply that the probability of having a higher implied than historical volatility is $2.3 \%$ larger with chosen compared with available underlyings and that of having a higher expected than historical dividend $6 \%$ larger. Thus, issuers design their products such that they have a stronger informational advantage regarding volatility and dividends. As shown in Columns (2) and (3), this result is also significant if we lag the matching variables by two and three weeks.

\section{Robustness}

We conduct several robustness tests for our main results.

\subsection{Product pricing}

In Tables 10 and 11, we discuss alternative specifications of the main regressions in Tables 3 and 4. A potential concern with our results is that they are driven by issuers installing higher IPs for certain product categories. A correlation of the unobserved heterogeneity 
on the product category level with at least one of the main explanatory variables could bias our conclusions. The same problem arises if certain issuers tend to require higher IPs than others. Thus, we rerun the regressions with product category and issuer fixed effects. Our results are robust to this alternative specifications, as shown in Column (1) of both tables.

\section{INSERT TABLE 10 NEAR HERE}

\section{INSERT TABLE 11 NEAR HERE}

So far, we assume that the impact of volatility and dividend on the IP is linear. To control for potential non-linear relations, we incorporate the square product of implied volatility (Implied Volatility Squared) and IBES Dividend Yield (IBES Dividend Yield Squared) into our regression model. Both Columns (2) show that our results remain qualitatively unchanged.

Another potential concern with the volatility result is that the IP is driven by the fact that retail investors demand a different volatility risk premium than institutional investors. We inlcude VSMI which is an index based on implied volatilities of SMI options across different maturities to control for time variation in risk premiums. The results in Column (3) of Table 10 are robust to the inclusion of the VSMI.

A potential error in the calculation of Impl Vola could introduce a correlation between the independent variable IP and the control variable Impl Vola or Higher Vola. The reason is that some structured products entail options (used to calculate the IP via the replication price) with maturity and strike that are close to those of the extracted control variable Impl Vola. We address this endogeneity concern with the approach suggested in Henderson and Pearson (2011). Specifically, we use the implied volatility of at-themoney put options with a time to maturity of 182 trading days (Implied Volatility 182) to define the controls Impl Vola and Higher Vola in our regressions. Whereas this implied volatility should still proxy for future expected volatility, none of our structured products is replicated with a 182 trading days at-the-money put option. Column (4) in Table 10 shows that our results are robust to this specification.

Next, we include a battery of additional control variables that potentially drive our results. The degree of competition in the structured products market may affect issuers' decision about the size of IPs. In a more competitive market, for example, competitors' price decisions could exert pressure on an issuer's premium. Thus, we incorporate the 
HH-Index as an additional control. HH-Index is the Herfindal-Hirshman-Index calculated based on the market shares of issuers in the number of products at each date. A higher value indicates a more monopolistic market ${ }^{12}$

Structured products may also serve banks as medium-term funding source. Thus, issuers' funding needs can influence their product pricing and issuance behavior. We control for funding needs with the quarterly ratio between deposit and total assets of each issuer.

Because investors face the default risk of the issuer when investing in a structured product, issuers may need to compensate investors for this risk Arnold, Schuette, and Wagner, 2016). As a consequence, the IP could depend on the issuer's creditworthiness. Thus, we incorporate the issuer's interpolated CDS spread as a proxy for default risk.

The economic environment also influences the market conditions to issue structured products. We include the values of the Economic Barometer published by the KOF Swiss Economic Institute as a proxy for economic environment. The Economic Barometer is based on the month-on-month growth rate of Switzerland's GDP and aims to indicate the Swiss business cycle.

We incorporate all four additional control variables in Column (5) of Table 10 and Column (3) of Table 11. The main results are robust to the specification with the additional controls. The negative and significant coefficient of CDS Spread indicates that products of issuers with higher default risk exhibit lower IPs. The coefficient of HH-Index is positive and significant in Table 11. Thus, in time periods with less competition, IPs are on average larger. Both findings are in line with our expectations. The remaining additional control variables are not statistically significant.

Another potential concern with our results is that the coefficients of our informational advantage measures are affected by cross-sectional heterogeneity of underlyings and correlated standard errors within underlying clusters. To address this concern, we also include underlying fixed effects and clustered standard errors at the underlying level in Column (6) of Table 10 and Column (4) of Table 11. Our results are robust to this specification.

\footnotetext{
${ }^{12} \mathrm{We}$ also use the number of active products and banks as alternative proxies for competition. The results are robust to these alternatives.
} 


\subsection{Regression discontinuity design}

Our RD results are robust to alternative methodologies and specifications.

As structured products entail derivative components, their return is not linearly related to the underlying. Therefore, we rerun the regression model 3 by including the quadratic term of Return Underlying and its interaction with Product Category. The jump at the threshold remains statistically significant.

Following the suggestion of Imbens and Lemieux (2008), we also investigate the sensitivity of our results to the bandwidths choice. Thus, we repeat the RD analysis by considering multiples of the originally chosen bandwidths. The magnitude of the discontinuity coefficient declines but remains statistically significant. For example, if we double (triple) the number of observations on both sides of the threshold, the coefficient is equal to $9.77 \%$ (4.92\%). As expected, statistical significance disappears for larger bandwidths because just-before products with a large distance of their ex-dividend date to the maturity date become just-after products in terms of the previous ex-dividend date (and vice versa).

We also implement the RD design based on bias-corrected RD estimators and robust standard errors as suggested by Calonico, Cattaneo, and Titiunik (2014). In this approach, we use a triangular kernel function to construct the local-polynomial estimator. Our results are robust to this alternative methodology (not reported).

\section{Conclusion}

We present evidence that the pricing and design of structured products are driven by the degree of the informational advantage of the issuer over retail investors. In particular, we show that products with a volatility information advantage for issuers have an issue premium which is approximately $30 \%$ larger than without this advantage, and products with a dividend information advantage for issuers have a $40 \%$ larger premium. Consistent with the hypothesis that issuers exploit their informational advantage, our results are stronger for products with a higher value sensitivity to the corresponding information and a larger portion of less sophisticated investors. The explanatory power of informational advantage proxies is important statistically and economically, whereas standard proxies for the production cost of structured products, the market environment, or liquidity are mostly insignificant. We also show that banks do not only exploit uninformed investors 
through the pricing of structured products, but even design products towards features of which investors are insufficiently informed. The structuring result is of systemic stability concern because it suggests that financial engineers actively contribute to imperfect information in the financial system.

There is a vivid ongoing debate on the caveats of financial innovation such as product complexity and investor sophistication (e.g., Carlin, 2009; Zingales, 2015, Célérier and Vallée, forthcoming). We contribute to this discussion with evidence that unequal access to information is an additional important caveat of financial innovations. Our results imply that the current product disclosure policy is insufficient to prevent financial engineers from exploiting their informational advantage over investors. The Dodd-Frank Act, for instance, only broadly suggests that adequate information should be given to investors. Hence, information exploitation appears to have largely escaped regulators in charge of investor protection. As a lack of investor information about financially engineered products causes market fragility (Rajan, 2006; Gorton and Metrick, 2012; Stein, 2012; Gennaioli, Shleifer, and Vishny, 2012), desirable regulatory policies should aim at mitigating this gap. By identifying the specific channels through which financial engineers exploit their informational advantage over investors, our study stimulates the discussion on whether and how to reduce informational differences between investors and financial engineers. Reducing this difference could mitigate issuers' incentive to design products for which investors have a large informational disadvantage and, thus, the concern that financial innovations undermine market stability. The content and exact form of information provisions seem fruitful directions for future research. For example, recent implied volatility estimations or predicted future dividends could be made available to investors of financially engineered securities. Such disclosure policies are an alternative to restricting the issuance of products to well informed and qualified investors. 


\section{Appendix: Replication prices}

Each structured product is replicated by using fixed income and option components.

Discount Certificates (DC) are replicated as

$$
D C=\frac{M}{\exp (r T)}-P\left(S-P V(D), M, T, \sigma_{P}\right)
$$

in which $M$ is the redemption amount of the bond component, $r$ the interest rate, $T$ the time to maturity of the product, and $P\left(S-P V(D), M, T, \sigma_{P}\right)$ a put option on the underlying of the product strike $M$ and time to maturity $T$. We adjust the spot price $S$ by subtracting $P V(D)$ that is the present value of all dividend payments predicted by IBES to occur during the lifetime of a product. $\sigma_{P}$ is the implied volatility of the put option with corresponding strike and maturity.

We replicate a Barrier Discount Certificate (BDC) as

$$
B D C=\frac{M}{\exp (r T)}+C\left(S-P V(D), Y, T, \sigma_{C}\right)-D I P\left(S-P V(D), X, B, T, \sigma_{D I P}\right)
$$

in which $M$ is the redemption value of the bond component, $r$ the interest rate, $T$ the time to maturity of the product, $C\left(S-P V(D), Y, T, \sigma_{C}\right)$ a call option on the underlying of the product with strike $Y$, time to maturity $T$ and implied volatility $\sigma_{C}$, and $D I P(S-$ $P V(D), X, B, T)$ a down and in put option on the underlying of the product with strike $X$, barrier level $B$, time to maturity $T$ and implied volatility $\sigma_{D I P}$.

Reverse Convertibles $(\mathrm{RC})$ are replicated by

$$
R C=\frac{N}{\exp (r T)}+\sum_{t_{i} \leq T} \frac{c_{t_{i}}}{\exp \left(r t_{i}\right)}-\alpha P\left(S-P V(D), X, T, \sigma_{P}\right)
$$

in which $N$ denotes the nominal amount, $t_{i}$ the coupon payment dates, $c_{t_{i}}$ the coupon payments at time $t_{i}$, and $P\left(S-P V(D), X, T, \sigma_{P}\right)$ a put option on the underlying of the product with strike $X$, time to maturity $T$ and implied volatility $\sigma_{P} . \alpha=N / X$ reflects the number of put options contained in the nominal amount of a certificate. 
We replicate Capped Outperformance Certificates (COC) as

$$
\begin{aligned}
& C O C=\frac{M}{\exp (r T)}-P\left(S-P V(D), M, T, \sigma_{P}\right)+ \\
& (\alpha-1) C\left(S, Y, T, \sigma_{C 1}\right)-(\alpha-1) C\left(S-P V(D), M, T, \sigma_{C 2}\right),
\end{aligned}
$$

in which $M$ is the redemption amount of the bond component, $Y$ the lower threshold of the underlying above which the investor disproportionately participates in the performance of the underlying, $\alpha$ the total participation rate between $Y$ and $M, C\left(S-P V(D), Y, T, \sigma_{C 1}\right)$ a call option with strike $Y$, time to maturity $T$ and implied volatility $\sigma_{C 1} . C(M, T)$ is a call option with strike $M$.

Barrier Reverse Convertibles (BRC) are replicated by

$$
B R C=\frac{N}{\exp (r T)}+\sum_{t_{i} \leq T} \frac{c_{t_{i}}}{\exp \left(r t_{i}\right)}-\alpha D I P\left(S-P V(D), X, B, T, \sigma_{D I P}\right)
$$

in which $\alpha$ is the number of put options contained in the nominal amount of a certificate, calculated as $\alpha=N / X$, and $D I P\left(S-P V(D), X, B, T, \sigma_{D I P}\right)$ a down and in put option on the underlying of the product with strike $X$, barrier $B$, time to maturity $T$ and implied volatility $\sigma_{D I P}$.

Finally, we construct Bonus Certificates (BC) with

$$
\begin{aligned}
& B C=\frac{M}{\exp (r T)}+C\left(S-P V(D), M, T, \sigma_{C}\right)- \\
& P\left(S-P V(D), M, T, \sigma_{P}\right)+\alpha D O P\left(S-P V(D), M, B, T, \sigma_{D O P}\right),
\end{aligned}
$$

in which $M$ is the redemption amount of the bond components, $\alpha$ the total participation rate, and $D O P\left(S-P V(D), X, B, T, \sigma_{D O P}\right)$ a down and out put option on the underlying of the product with strike $M$, barrier $B$, time to maturity $T$ and implied volatility $\sigma_{D O P}$.

We obtain the option components in a replication price by transforming traded (American) EUREX option prices to the (European) option prices of the structured product. For an accurate transformation, we need the expected dividend and implied volatility of the underlying, as well as the pricing parameters provided in the term sheet of each product at the initial fixing date.

We collect consensus dividend forecasts from IBES. For each product, we use the IBES database's latest mean expected dividend entry prior to the initial fixing date to forecast 
the dividend amount paid during a product's lifetime. We obtain expected ex-dividend dates by projecting historical ex-dividend dates within a year prior to the initial fixing of a product into the future. Using discrete dividends in our analysis is important to investigate the dependence of structured products' performance on the relation between product maturity and ex-dividend dates.

We extract implied volatilities from traded EUREX options. For each option contained in a structured product, we identify four corresponding EUREX options: One with the closest lower strike price and closest longer maturity, the closest lower strike price and closest shorter maturity, the closest higher strike price and closest longer maturity, and the closest higher strike price and closest shorter maturity. If we do not find all four options, we use the EUREX option that most closely matches the maturity and the strike price of a product's implicit option (e.g. Henderson and Pearson (2011)). As EUREX options are of American type, we extract each implied volatility by using a binomial tree model based on Cox, Ross, and Rubinstein (1979). We apply a daily discretization for the tree with $p=\left(e^{r(1 / 360)}-d\right) /(u-d), q=1-p, u=e^{\sigma \sqrt{(1 / 360)}}$, and $d=1 / u$, in which $p(q)$ is the probability of an increase (decrease), and $u(d)$ is the discrete factor for an increase (decrease) in the stock price. We incorporate the discrete dividend payments in the binomial tree. We obtain the implied volatility of an option by extracting the volatility in the tree that equates the tree's option price with the observed EUREX option settlement price. Subsequently, we bilinearly interpolate the implied volatilities of the four corresponding EUREX options based on their distance to the strike and the time to maturity of the option contained in the structured product.

For the interest rate, $r$, we follow the literature by using interpolated London Interbank Offered Rates (LIBOR) in the currency of the structured product for different maturities (Henderson and Pearson, 2011). For maturities beyond twelve months, we apply the corresponding swap rates. As the maturity of a structured product hardly ever matches the maturity of publicly available LIBOR rates exactly, we linearly interpolate for each product the LIBOR rates with the closest longer and the closest shorter maturities to obtain an estimation for the appropriate interest rate.

Because structured products in our sample entail only options of European type, we apply the Black-Scholes formula to price the plain vanilla options contained in a product. Barrier options are calculated by using the formula of Hull (2009) for knock-in and knock-out options. We incorporate the estimated dividends, implied volatility, and 
interest rate. The stock price relevant to calculate the replication price of structured products is $S-P V(D)$, in which $S$ is the market price of the underlying at the initial fixing date and $P V(D)$ is the present value of the dividend payments that are expected to occur during a product's lifetime 


\section{References}

An, Xudong, Yongheng Deng, and Gabriel Stuart, 2011, Asymmetric information, adverse selection, and the pricing of cmbs, Journal of Financial Economics 100, 304-325.

Arnold, Marc, Dustin Schuette, and Alexander Wagner, 2016, Neglected risk in financial innovations: Evidende from structured product counterparty exposure, Unpublished Working Paper.

Ashcraft, Adam B., and Til Schuermann, 2008, Understanding the securitization of subprime mortgage credit, Unpu.

Battalio, Robert H., and Richard R. Mendenhall, 2005, Earnings expectations, investor trade size, and anomalous returns around earnings announcements, Journal of Financial Economics 77, 289-319.

Baule, Rainer, Oliver Entrop, and Marco Wilkens, 2008, Credit risk and bank margins in structured financial products: Evidence from the German secondary market for discount certificates, Journal of Futures Markets 28, 376-397.

Benet, Bruce A., Antoine Giannetti, and Seema Pissaris, 2006, Gains from structured product markets: The case of reverse-exchangeable securities (RES), Journal of Banking $\&$ Finance 30, 111-132.

Bhattacharya, Nilabhra, 2001, Investors' trade size and trading responses around earnings announcements: An empirical investigation, The Accounting Review 76, 221-244. 
— Ervin L. Black, Theodore E. Christensen, and Richard D. Mergenthaler, 2007, Who trades on pro forma earnings information?, The Accounting Review 82, 581-619. Bhattacharya, Utpal, Andreas Hackethal, Simon Kaesler, Benjamin Loos, and Steffen Meyer, 2012, Is unbiased financial advice to retail investors sufficient? Answers from a large field study, The Review of Financial Studies 25, 975-1032.

Bloomberg Brief: Structured Notes, 2015, 2014 year in review, Special Report.

Bouveret, Antoine, Ricardo Crisóstomo, Monica Gentile, Victor Mendes, Paulo Pereira da Silva, and Fernando Silva, 2013, Economic report: retailisation in the EU, European Securities and Markets Authority.

Burth, Stefan, Thomas Kraus, and Hanspeter Wohlwend, 2001, The pricing of structured products in the Swiss market, Journal of Derivatives 9, 30-40.

Calonico, Sebastian, Matias D. Cattaneo, and Rocio Titiunik, 2014, Robust nonparametric confidence intervals for regression-discontinuity designs, Econometrica 82, 22952326.

Carlin, Bruce, and Gustavo Manso, 2011, Obfuscation, learning, and the evolution of investor sophistication, The Review of Financial Studies 24, 754-785.

Carlin, Bruce I, 2009, Strategic price complexity in retail financial markets, Journal of Financial Economics 91, 278-287.

Carr, Peter, and Liuren $\mathrm{Wu}, 2016$, Analyzing volatility risk and risk premium in option contracts: A new theory, Journal of Financial Economics 120, 1-20. 
Célérier, Claire, and Boris Vallée, forthcoming, Catering to investors through product complexity, The Quarterly Journal of Economics.

Chae, Joon, 2005, Trading volume, information asymmetry, and timing information, Journal of Finance 60, 413-442.

Chang, Yen-Cheng, Harrison Hong, and Inessa Liskovich, 2014, Regression discontinuity and the price effects of stock market indexing, The Review of Financial Studies 28, $212-246$.

Choi, James, David Laibson, and Brigitte Madrian, 2009, Why does the law of one price fail? An experiment on index mutual funds, The Review of Financial Studies 23, $1405-1432$.

Coval, Joshua, Jakub Jurek, and Erik Stafford, 2009, The economics of structured finance, Journal of Economic Perspectives 23, 3-25.

Cox, John, Stephen Ross, and Mark Rubinstein, 1979, Option pricing: A simplified approach, Journal of Financial Economics 7, 229-263.

Daniel, Kent, David Hirshleifer, and Siew H. Teoh, 2002, Investor psychology in capital markets: Evidence and policy implications, Journal of Monetary Economics 49, 139209.

DeMarzo, Peter, 2005, The pooling and tranching of securities: A model of informed intermediation, The Review of Financial Studies 18, 1-35. 
Gennaioli, Nicola, Andrei Shleifer, and Robert Vishny, 2012, Neglected risks, financial innovation, and financial fragility, Journal of Financial Economics 104, 452-468.

Gorton, Gary, and Andrew Metrick, 2012, Securitized banking and the run on repo, Journal of Financial Economics 104, 425-451.

Hanson, Samuel G., and Adi Sunderam, 2013, Are there too many safe securities? Securitization and the incentives for information production, Journal of Financial Economics $108,565-584$.

Henderson, Brian J., and Neil D. Pearson, 2011, The dark side of financial innovation: A case study of the pricing of a retail financial product, Journal of Financial Economics $100,227-247$.

Hens, Thorsten, and Marc Oliver Rieger, 2014, Can utility optimization explain the demand for structured investment products?, Quantitative Finance 14, 673-681.

Hull, John C., 2009, Options, Futures, and Other Derivatives (Pearson, Prentice Hall).

Imbens, Guido W., and Thomas Lemieux, 2008, Regression discontinuity designs: A guide to practice, Journal of Econometrics 142, 615-635.

Investment Company Institute, 2015, A review of trends and activities in the U.S., Investment Company Fact Book.

Lee, David S., and Thomas Lemieux, 2010, Regression discontinuity designs in economics, Journal of Economic Literature 48, 281-355. 
McCrary, Justin, 2008, Manipulation of the running variable in the regression discontinuity design: A density test, Journal of Econometrics 142, 698-714.

Piskorski, Tomasz, Amit Seru, and James Witkin, 2015, Asset quality misrepresentation by financial intermediaries: Evidence from the RMBS market, The Journal of Finance $70,2635-2678$.

Rajan, Raghuram G., 2006, Has finance made the world riskier?, European Financial Managment 12, 499-533.

Rieger, Marc Oliver, 2012, Why do investors buy bad financial products? Probability misestimation and preferences in financial investment decision, Journal of Behavioral Finance 13, 108-118.

Sirri, Erik R., and Peter Tufano, 1998, Costly search and mutual fund flows, The Journal of Finance 53, 1589-1622.

Stein, Jeremy C., 2012, Monetary policy as financial-stability regulation, The Quarterly Journal of Economics 127, 57-95.

Stoimenov, Pavel A., and Sascha Wilkens, 2005, Are structured products fairly priced? An analysis of the German market for equity-linked instruments, Journal of Banking and Finance 29, 2971-2993.

Structured Retail Products, 2015, Analysis on structured products and listed equity options in Europe: An industry overview and future prospects, Research Report for the Options Industry Council. 
SVSP, Schweizerischer Verband für Strukturierte Produkte, 2013, Marktreport Strukturierte Produkte, Quartalsbericht.

Swiss Bankers Association, 2011, Wealth management in Switzerland: Status report and trends, Basel.

Wallmeier, Martin, and Martin Diethelm, 2009, Market pricing of exotic structured products: The case of multi-asset barrier reverse convertibles in Switzerland, Journal of Derivatives 17, 59-72.

Wilkens, Sascha, Carsten Erner, and Klaus Röder, 2003, The pricing of structured products in Germany, Journal of Derivatives 11, 55-69.

Zingales, Luigi, 2015, Presidential address: Does finance benefit society?, The Journal of Finance 70, 1327-1363. 
Table 1

Overview of Structured Products Sample

This table presents the number of structured products in our sample grouped by issuer, product category, and year. Our starting point is a term sheets database containing all structured equity products issued in Switzerland between January 2005 and December 2010. We collect data on products issued in Switzerland on a single equity underlying.

Number of Issued Products

\begin{tabular}{lc}
\hline Panel A: By Issuer & \\
\hline UBS & 550 \\
Goldman Sachs & 144 \\
Credit Suisse & 136 \\
Royal Bank of Scotland & 134 \\
Deutsche Bank & 29 \\
Merrill Lynch & 11 \\
J.P. Morgan & 8 \\
Panel B: By Product Category & \\
\hline Discount Certificate & 358 \\
Barrier Reverse Convertible & 295 \\
Bonus Certificate & 188 \\
Reverse Convertible & 97 \\
Capped Outperformance Certificate & 54 \\
Barrier Discount Certificate & 20 \\
Panel C: By Year & \\
\hline 2005 & 73 \\
2006 & 165 \\
2007 & 249 \\
2008 & 272 \\
2009 & 178 \\
2010 & 75 \\
\hline \hline
\end{tabular}




\section{Table 2}

\section{Descriptive Statistics}

This table presents descriptive statistics for our sample of structured products issued in Switzerland between January 2005 and December 2010. We collect data on products on a single equity underlying. Issue Premium (IP) is the issue price of a structured product minus its replication value, scaled by the issue price, expressed in percentage points. ImplVola is the annualized implied volatility of the product's option on the underlying calculated for the lifetime of the product. We calculate Hist Vola as the standard deviation of a product underlying's returns over the 255 trading days before the initial fixing date. IBES Div Yield is the ratio between the present value of expected dividend payments based on IBES forecasts that occur during the lifetime of a product and the stock price of the underlying at the initial fixing date. We define Hist Dividend Yield as the ratio between the present value of the expected dividend payments based on historical dividend payment patterns and the stock price of the underlying at the initial fixing date. Market Cap Underlying is the natural logarithm of the market value of equity of the underlying (in USDbn). 3m and 12m Excess Return Underlying are the 3 and 12 months continuous annual returns of the underlying in excess of the 3 and 12 months continuous annual returns of the Swiss Market Index (SMI), respectively. $1 \mathrm{~m}$ and $3 \mathrm{~m}$ Turnover Underlying are defined as the natural logarithm of the dollar value (in USDm) of the cumulated trading volume of the underlying over one month and three month prior to the issuance, respectively. We calculate $1 \mathrm{~m}$ Call Volume and $1 \mathrm{~m}$ Put Volume as the cumulated trading volume of EUREX call (put) options written on the underlying over one month preceding the initial fixing date divided by the volume of call (put) options written on all underlyings during the same time period. Vega (Delta) is the product's annualized Vega (Delta) scaled by its issue price. Average Trading Size is the logarithm of the average trading size in USD on the secondary market. Features is defined as the number of different features contained in a product whereas each strike, barrier, or the presence of coupon payments adds one additional feature to a structured product. We calculate Implied Volatility Squared as the square product of Impl Vola, Implied Volatility 182 as the annualized implied volatility of an at-the-money put option with a maturity of 182 days on the product's underlying and IBES Div Yield Squared as the square product of IBES Div Yield. Time to Maturity is defined as the number of business days between the initial fixing date and maturity date of a structured product.

\begin{tabular}{lcccccc}
\hline & $\mathrm{N}$ & Mean & $\begin{array}{c}\text { Std. } \\
\text { Dev. }\end{array}$ & Q25 & Median & Q75 \\
& & & & & \\
\hline Issue Premium & 1012 & 1.48 & 2.09 & 0.52 & 1.35 & 2.24 \\
Impl Vola & 1012 & 28.67 & 11.26 & 21.27 & 26.18 & 33.95 \\
Hist Vola & 1012 & 31.24 & 18.59 & 18.85 & 24.40 & 36.69 \\
IBES Div Yield & 1012 & 0.03 & 0.02 & 0.01 & 0.03 & 0.04 \\
Hist Div Yield & 1012 & 0.04 & 0.06 & 0.01 & 0.02 & 0.04 \\
Market Cap Underlying & 1012 & 3.80 & 1.09 & 3.26 & 4.08 & 4.70 \\
3m Excess Return Underlying (x100) & 1012 & 1.46 & 11.09 & -5.26 & 1.35 & 8.44 \\
12m Excess Return Underlying (x100) & 1012 & 0.87 & 21.26 & -11.48 & 0.18 & 12.75 \\
1m Turnover Underlying & 1012 & 7.45 & 1.92 & 6.15 & 8.21 & 8.98 \\
3m Turnover Underlying & 1012 & 8.55 & 1.91 & 7.24 & 9.27 & 10.06 \\
1m Call Option Volume & 1012 & 2.63 & 3.79 & 0.31 & 1.66 & 3.13 \\
1m Put Option Volume & 1012 & 2.55 & 3.41 & 0.33 & 1.66 & 3.27 \\
Vega & 1012 & -0.46 & 0.29 & -0.49 & -0.43 & -0.39 \\
Delta & 1012 & 0.02 & 0.18 & 0.01 & 0.01 & 0.02 \\
Average Trading Size (in USD 1000) & 783 & 10.71 & 1.15 & 9.98 & 10.68 & 11.33 \\
Features & 1012 & 2.18 & 0.92 & 1.00 & 3.00 & 3.00 \\
Implied Volatility Squared & 1012 & 9.49 & 8.40 & 4.52 & 6.85 & 11.52 \\
Implied Volatility 182 & 994 & 31.19 & 14.73 & 21.65 & 28.32 & 37.46 \\
IBES Div Yield Squared (x100) & 1012 & 0.12 & 0.17 & 0.01 & 0.06 & 0.15 \\
Time to Maturity (trading days) & 1012 & 294.16 & 150.80 & 249 & 255 & 265 \\
\hline \hline
\end{tabular}




\section{Table 3}

\section{OLS Regressions of the Issue Premiums for Volatility Measures}

This table presents results of OLS regressions. The dependent variable is the Issue Premium (IP), which is the issue price of a structured product minus its replication value, scaled by the issue price, expressed in percentage points. Impl Vola is the annualized implied volatility of the product's option on the underlying calculated for the lifetime of the product. We calculate Hist Vola as the standard deviation of a product underlying's returns over the 255 trading days before the initial fixing date. Higher Vola is a binary variable that is equal to one if Impl Vola is larger than Hist Vola, and zero otherwise. Vega is defined as the product's annualized Vega scaled by its issue price. Average Trading Size is calculated as the logarithm of the average trading size in USD on the secondary market. Features is defined as the number of different features contained in a product whereas each strike, barrier, or the presence of coupon payments adds one additional feature to a structured product. The standard controls are defined in Table 2 . We control for year fixed effects. $t$-statistics are reported in parentheses. ${ }^{*},{ }^{* *}$, and ${ }^{* * *}$ denote significance at the $10 \%, 5 \%$, and $1 \%$ level, respectively.

\begin{tabular}{|c|c|c|c|c|c|c|}
\hline VARIABLES & $\begin{array}{l}1) \\
\text { IP }\end{array}$ & $\begin{array}{l}(2) \\
\text { IP }\end{array}$ & $\begin{array}{l}(3) \\
\text { IP }\end{array}$ & $\begin{array}{l}(4) \\
\text { IP }\end{array}$ & $\begin{array}{l}(5) \\
\text { IP }\end{array}$ & $\begin{array}{l}6) \\
\text { IP }\end{array}$ \\
\hline Impl Vola & $\begin{array}{c}4.879 * * * \\
(6.41)\end{array}$ & $\begin{array}{c}8.372^{* * *} \\
(7.40)\end{array}$ & $\begin{array}{c}1.272^{* * *} \\
(10.42)\end{array}$ & $\begin{array}{c}8.275^{* * *} \\
(7.37)\end{array}$ & $\begin{array}{c}7.063^{* * *} \\
(6.38)\end{array}$ & $\begin{array}{c}9.389 * * * \\
(8.68)\end{array}$ \\
\hline Hist Vola & & $\begin{array}{c}-4.440 * * * \\
(-5.07)\end{array}$ & $\begin{array}{c}-0.894^{* * *} \\
(-5.79)\end{array}$ & $\begin{array}{c}-4.678 * * * \\
(-5.37)\end{array}$ & $\begin{array}{c}-2.551^{* * *} \\
(-2.98)\end{array}$ & $\begin{array}{c}-6.147^{* * * *} \\
(-7.23)\end{array}$ \\
\hline Higher Vola & & $\begin{array}{c}0.542^{* * *} \\
(3.22)\end{array}$ & & $\begin{array}{l}0.091 \\
(0.34)\end{array}$ & $\begin{array}{c}3.074^{* * *} \\
(2.67)\end{array}$ & $\begin{array}{c}0.479^{* * *} \\
(2.99)\end{array}$ \\
\hline Impl Vola $\times$ Hist Vola & & & $\begin{array}{c}-0.196 * * * \\
(-3.15)\end{array}$ & & & \\
\hline Vega & & & & $\begin{array}{c}1.142^{* * *} \\
(4.30)\end{array}$ & & \\
\hline Higher Vola $\times$ Vega & & & & $\begin{array}{c}-0.803^{*} \\
(-1.86)\end{array}$ & & \\
\hline Average Trading Size & & & & & $\begin{array}{l}0.001 \\
(0.02)\end{array}$ & \\
\hline Higher Vola $\times$ Average Trading Size & & & & & $\begin{array}{c}-0.230^{* *} \\
(-2.14)\end{array}$ & \\
\hline Features & & & & & & $\begin{array}{c}0.728^{* * *} \\
(10.29)\end{array}$ \\
\hline Market Cap Underlying & $\begin{array}{c}0.164^{* *} \\
(2.24)\end{array}$ & $\begin{array}{l}0.105 \\
(1.47)\end{array}$ & $\begin{array}{c}0.186^{* *} \\
(2.49)\end{array}$ & $\begin{array}{l}0.097 \\
(1.36)\end{array}$ & $\begin{array}{l}0.096 \\
(1.36)\end{array}$ & $\begin{array}{l}-0.042 \\
(-0.60)\end{array}$ \\
\hline 3m Excess Return Underlying & $\begin{array}{l}0.793 \\
(1.29)\end{array}$ & $\begin{array}{c}1.522^{* *} \\
(2.52)\end{array}$ & $\begin{array}{c}1.829^{* * *} \\
(2.99)\end{array}$ & $\begin{array}{c}1.662^{* * * *} \\
(2.77)\end{array}$ & $\begin{array}{l}-0.003 \\
(-0.01)\end{array}$ & $\begin{array}{c}1.616^{* * *} \\
(2.82)\end{array}$ \\
\hline 12m Excess Return Underlying & $\begin{array}{l}-0.432 \\
(-1.34)\end{array}$ & $\begin{array}{c}-0.565^{*} \\
(-1.81)\end{array}$ & $\begin{array}{c}-1.045^{* * *} \\
(-3.06)\end{array}$ & $\begin{array}{c}-0.546^{*} \\
(-1.76)\end{array}$ & $\begin{array}{l}-0.159 \\
(-0.49)\end{array}$ & $\begin{array}{l}-0.446 \\
(-1.50)\end{array}$ \\
\hline 1m Turnover Underlying & $\begin{array}{l}0.185 \\
(0.64)\end{array}$ & $\begin{array}{l}-0.119 \\
(-0.42)\end{array}$ & $\begin{array}{l}0.009 \\
(0.03)\end{array}$ & $\begin{array}{l}-0.111 \\
(-0.40)\end{array}$ & $\begin{array}{l}0.322 \\
(1.16)\end{array}$ & $\begin{array}{l}-0.309 \\
(-1.15)\end{array}$ \\
\hline 3m Turnover Underlying & $\begin{array}{l}-0.221 \\
(-0.76)\end{array}$ & $\begin{array}{l}0.101 \\
(0.36)\end{array}$ & $\begin{array}{l}-0.025 \\
(-0.09)\end{array}$ & $\begin{array}{l}0.099 \\
(0.35)\end{array}$ & $\begin{array}{l}-0.315 \\
(-1.12)\end{array}$ & $\begin{array}{l}0.313 \\
(1.16)\end{array}$ \\
\hline 1m Call Option Volume & $\begin{array}{l}-1.673 \\
(-0.49)\end{array}$ & $\begin{array}{l}0.069 \\
(0.02)\end{array}$ & $\begin{array}{l}-0.955 \\
(-0.29)\end{array}$ & $\begin{array}{l}0.337 \\
(0.10)\end{array}$ & $\begin{array}{l}-1.470 \\
(-0.34)\end{array}$ & $\begin{array}{l}1.113 \\
(0.35)\end{array}$ \\
\hline 1m PutOption Volume & $\begin{array}{l}3.754 \\
(0.98)\end{array}$ & $\begin{array}{l}3.184 \\
(0.86)\end{array}$ & $\begin{array}{l}3.301 \\
(0.89)\end{array}$ & $\begin{array}{l}2.721 \\
(0.74)\end{array}$ & $\begin{array}{l}5.250 \\
(1.16)\end{array}$ & $\begin{array}{c}1.013 \\
(0.29)\end{array}$ \\
\hline Constant & $\begin{array}{l}0.020 \\
(0.04)\end{array}$ & $\begin{array}{c}1.047^{* *} \\
(2.15)\end{array}$ & $\begin{array}{l}-0.650 \\
(-1.23)\end{array}$ & $\begin{array}{c}1.220^{* *} \\
(2.08)\end{array}$ & $\begin{array}{l}-0.682 \\
(-1.32)\end{array}$ & $\begin{array}{l}-0.983 \\
(-1.60)\end{array}$ \\
\hline Year fixed effects & Yes & Yes & Yes & Yes & Yes & Yes \\
\hline Observations & 1,012 & 1,012 & 1,012 & 1,012 & 783 & 1,012 \\
\hline R-squared & 0.133 & 0.188 & 0.187 & 0.203 & 0.157 & 0.266 \\
\hline
\end{tabular}


Table 4

OLS Regressions of the Issue Premiums for Dividend Measures

This table presents results of OLS regressions. The dependent variable is the Issue Premium (IP), which is the issue price of a structured product minus its replication value, scaled by the issue price, expressed in percentage points. IBES Div Yield is the ratio between the present value of expected dividend payments based on IBES forecasts that occur during the lifetime of a product and the stock price of the underlying at the initial fixing date. We define Hist Dividend Yield as the ratio between the present value of the expected dividend payments based on historical dividend payment patterns and the stock price of the underlying at the initial fixing date. Higher Div is a binary variable that is equal to one if IBES Dividend Yield is larger than Hist Dividend Yield, and zero otherwise. Delta is defined as the product's annualized Delta scaled by its issue price. Average Trading Size is calculated as the logarithm of the average trading size in USD on the secondary market. Features is defined as the number of different features contained in a product whereas each strike, barrier, or the presence of coupon payments adds one additional feature to a structured product. The standard controls are defined in Table 2. We control for year fixed effects. $t$-statistics are reported in parentheses. ${ }^{*},{ }^{* *}$, and $^{* * *}$ denote significance at the $10 \%, 5 \%$, and $1 \%$ level, respectively.

\begin{tabular}{|c|c|c|c|c|c|c|}
\hline VARIABLES & $\begin{array}{l}(1) \\
\text { IP }\end{array}$ & $\begin{array}{l}(2) \\
\text { IP }\end{array}$ & $\begin{array}{l}(3) \\
\text { IP }\end{array}$ & $\begin{array}{l}(4) \\
\text { IP }\end{array}$ & $\begin{array}{l}5) \\
\mathrm{IP}\end{array}$ & $\begin{array}{l}6) \\
\text { IP }\end{array}$ \\
\hline IBES Div Yield & $\begin{array}{c}6.751^{* *} \\
(2.14)\end{array}$ & $\begin{array}{l}3.009 \\
(0.82)\end{array}$ & $\begin{array}{c}0.218^{* *} \\
(2.10)\end{array}$ & $\begin{array}{l}2.261 \\
(0.61)\end{array}$ & $\begin{array}{l}-5.244 \\
(-1.41)\end{array}$ & $\begin{array}{l}2.258 \\
(0.63)\end{array}$ \\
\hline Hist Div Yield & & $\begin{array}{c}-2.723^{*} \\
(-2.58)\end{array}$ & $\begin{array}{l}0.006 \\
(0.06)\end{array}$ & $\begin{array}{c}-4.438^{* * * *} \\
(-1.71)\end{array}$ & $\begin{array}{l}-1.335 \\
(-1.34)\end{array}$ & $\begin{array}{l}-1.335 \\
(-1.23)\end{array}$ \\
\hline Higher Div & & $\begin{array}{c}0.616^{* * *} \\
(3.78)\end{array}$ & & $\begin{array}{l}0.279 \\
(1.51)\end{array}$ & $\begin{array}{c}3.287^{* * * *} \\
(2.76)\end{array}$ & $\begin{array}{c}0.581^{* * * *} \\
(3.66)\end{array}$ \\
\hline IBES Div Yield $\times$ Hist Div Yield & & & $\begin{array}{c}-0.112^{* *} \\
(-2.23)\end{array}$ & & & \\
\hline Delta & & & & $\begin{array}{c}-20.852^{* * *} \\
(-4.15)\end{array}$ & & \\
\hline Higher Div $\times$ Delta & & & & $\begin{array}{c}24.161^{* * *} \\
(3.57)\end{array}$ & & \\
\hline Average Trading Size & & & & & $\begin{array}{l}0.076 \\
(0.85)\end{array}$ & \\
\hline Higher Div $\times$ Average Trading Size & & & & & $\begin{array}{c}-0.254^{* *} \\
(-2.30)\end{array}$ & \\
\hline Features & & & & & & $\begin{array}{c}0.542^{* * *} \\
(7.36)\end{array}$ \\
\hline Impl Vola & $\begin{array}{c}5.260 * * * \\
(6.74)\end{array}$ & $\begin{array}{c}6.053^{* * *} \\
(7.76)\end{array}$ & $\begin{array}{c}5.677^{* * * *} \\
(7.29)\end{array}$ & $\begin{array}{c}6.365^{* * *} \\
(8.18)\end{array}$ & $\begin{array}{c}5.859 * * * \\
(7.73)\end{array}$ & $\begin{array}{c}5.468^{* * * *} \\
(7.15)\end{array}$ \\
\hline Market Cap Underlying & $\begin{array}{c}0.145^{*} \\
(1.96)\end{array}$ & $\begin{array}{l}0.103 \\
(1.40)\end{array}$ & $\begin{array}{c}0.137^{*} \\
(1.87)\end{array}$ & $\begin{array}{l}0.107 \\
(1.47)\end{array}$ & $\begin{array}{l}0.113 \\
(1.56)\end{array}$ & $\begin{array}{l}0.005 \\
(0.06)\end{array}$ \\
\hline 3m Excess Return Underlying & $\begin{array}{l}0.785 \\
(1.28)\end{array}$ & $\begin{array}{l}0.690 \\
(1.14)\end{array}$ & $\begin{array}{l}0.653 \\
(1.07)\end{array}$ & $\begin{array}{l}0.578 \\
(0.96)\end{array}$ & $\begin{array}{l}-0.432 \\
(-0.69)\end{array}$ & $\begin{array}{l}0.696 \\
(1.18)\end{array}$ \\
\hline 12m Excess Return Underlying & $\begin{array}{l}-0.319 \\
(-0.98)\end{array}$ & $\begin{array}{l}-0.465 \\
(-1.45)\end{array}$ & $\begin{array}{l}-0.411 \\
(-1.27)\end{array}$ & $\begin{array}{l}-0.489 \\
(-1.53)\end{array}$ & $\begin{array}{l}-0.199 \\
(-0.61)\end{array}$ & $\begin{array}{l}-0.306 \\
(-0.97)\end{array}$ \\
\hline 1m Turnover Underlying & $\begin{array}{l}0.218 \\
(0.76)\end{array}$ & $\begin{array}{l}0.208 \\
(0.74)\end{array}$ & $\begin{array}{l}0.240 \\
(0.85)\end{array}$ & $\begin{array}{l}0.239 \\
(0.85)\end{array}$ & $\begin{array}{c}0.514^{*} \\
(1.85)\end{array}$ & $\begin{array}{l}0.095 \\
(0.34)\end{array}$ \\
\hline 3m Turnover Underlying & $\begin{array}{l}-0.249 \\
(-0.86)\end{array}$ & $\begin{array}{l}-0.227 \\
(-0.80)\end{array}$ & $\begin{array}{l}-0.264 \\
(-0.92)\end{array}$ & $\begin{array}{l}-0.251 \\
(-0.89)\end{array}$ & $\begin{array}{c}-0.508^{*} \\
(-1.80)\end{array}$ & $\begin{array}{l}-0.102 \\
(-0.37)\end{array}$ \\
\hline 1m Call Option Volume & $\begin{array}{l}-1.120 \\
(-0.33)\end{array}$ & $\begin{array}{l}-0.559 \\
(-0.17)\end{array}$ & $\begin{array}{l}-0.905 \\
(-0.27)\end{array}$ & $\begin{array}{l}-1.098 \\
(-0.33)\end{array}$ & $\begin{array}{l}-4.007 \\
(-0.91)\end{array}$ & $\begin{array}{l}-0.141 \\
(-0.04)\end{array}$ \\
\hline 1m Put Option Volume & $\begin{array}{l}2.765 \\
(0.72)\end{array}$ & $\begin{array}{l}1.613 \\
(0.43)\end{array}$ & $\begin{array}{l}1.961 \\
(0.51)\end{array}$ & $\begin{array}{l}2.303 \\
(0.61)\end{array}$ & $\begin{array}{l}6.434 \\
(1.40)\end{array}$ & $\begin{array}{l}0.383 \\
(0.10)\end{array}$ \\
\hline Constant & $\begin{array}{l}-0.106 \\
(-0.20)\end{array}$ & $\begin{array}{l}-0.502 \\
(-0.95)\end{array}$ & $\begin{array}{l}0.211 \\
(0.40)\end{array}$ & $\begin{array}{l}-0.306 \\
(-0.58)\end{array}$ & $\begin{array}{l}-1.032 \\
(-0.92)\end{array}$ & $\begin{array}{c}-1.095^{* *} \\
(-2.10)\end{array}$ \\
\hline Year fixed effects & Yes & Yes & Yes & Yes & Yes & Yes \\
\hline Observations & 1,012 & 1,012 & 1,012 & 1,012 & 783 & 1,012 \\
\hline R-squared & 0.137 & 0.166 & 0.157 & 0.180 & 0.135 & 0.209 \\
\hline
\end{tabular}




\section{Table 5}

\section{OLS Regression of the Unexplained Performance}

This table presents results using an OLS regression. The dependent variable is the Product Performance, which is the annualized performance of a structured product calculated as the return of the final payoff over the issue price. Underlying Return is the annualized total return of the underlying of a product multiplied by delta. We use Product Category fixed effects and the interaction between them and Underlying Return. $t$-statistics are reported in parentheses. ${ }^{*},{ }^{* *}$, and ${ }^{* * *}$ denote significance at the $10 \%, 5 \%$, and $1 \%$ level, respectively.

\begin{tabular}{|c|c|}
\hline VARIABLES & $\begin{array}{c}(1) \\
\text { Return Product }\end{array}$ \\
\hline Underlying Return & $\begin{array}{c}0.879^{* * *} \\
(9.35)\end{array}$ \\
\hline $\begin{array}{l}\text { Product Category Fixed Effects } \\
\text { Product Category Fixed Effects Interaction }\end{array}$ & $\begin{array}{l}\text { Yes } \\
\text { Yes }\end{array}$ \\
\hline $\begin{array}{l}\text { Observations } \\
\text { R-squared }\end{array}$ & $\begin{array}{c}1012 \\
0.900\end{array}$ \\
\hline
\end{tabular}

\section{Table 6}

Fuzzy RD Design: First-Stage Regression

This table presents the first-stage regression from a Fuzzy RD Design. The dependent variable is ExPost, a dummy that is equal to one if the actual (ex-post) dividend payment date closest to the maturity date occured after product maturity, and zero otherwise. Days is calculated as the difference between the estimated ex-dividend date closest to the maturity date and the maturity date measured in days. ExAnte is a dummy equal to one if the estimated ex-dividend date closest to the maturity date occured after product maturity, and zero otherwise. We apply optimal bandwidths based on the rule-of-thumb approach. $t$-statistics are reported in parentheses. ${ }^{*},{ }^{* *}$, and ${ }^{* * *}$ denote significance at the $10 \%, 5 \%$, and $1 \%$ level, respectively.

\begin{tabular}{lc}
\hline VARIABLES & $(1)$ \\
Ex-Post \\
\hline Days & 0.001 \\
& $(0.12)$ \\
Ex Ante & $0.688^{* * *}$ \\
& $(5.77)$ \\
Days x Ex Ante & 0.005 \\
& $(0.43)$ \\
\hline \multirow{2}{*}{ Observations } & 137 \\
R-squared & 0.554 \\
F & 57.40 \\
\hline \hline
\end{tabular}




\section{Table 7}

Fuzzy RD Design: Second-Stage Regression

This table presents results of the Fuzzy RD Design using a two-stage least-squares approach with local polynomials of order one. First, we use dividend payment dates projections to instrument the actual ex-post outcome based on Eqn. (4). Second, we use the fitted values from the first-stage regression as an instrument in Eqn. (5). The dependent variable is the unexplained performance measure (UP), which is defined as the residuals of the model estimated with Eqn(3). We apply optimal bandwidths based on the rule-of-thumb approach. We report the coefficients of discontinuity $\alpha_{2}$ estimated in Eqn. (5) for thresholds at different cut-offs in a time window of six weeks around day 0 . The thresholds are defined as the differences between the estimated ex-dividend date closest to the maturity date and the maturity date measured in days. $t$-statistics are reported in parentheses. ${ }^{*},{ }^{* *}$, and ${ }^{* * *}$ denote significance at the $10 \%, 5 \%$, and $1 \%$ level, respectively.

\begin{tabular}{|c|c|c|c|c|c|c|c|c|}
\hline & -15 & -14 & -13 & -12 & -11 & -10 & -9 & -8 \\
\hline$\alpha_{2}$ & $\begin{array}{l}-0.099 \\
(-0.56)\end{array}$ & $\begin{array}{l}-0.010 \\
(-0.13)\end{array}$ & $\begin{array}{l}0.010 \\
(0.21)\end{array}$ & $\begin{array}{l}0.015 \\
(0.35)\end{array}$ & $\begin{array}{l}-0.014 \\
(-0.30)\end{array}$ & $\begin{array}{l}0.047 \\
(0.55)\end{array}$ & $\begin{array}{l}0.081 \\
(1.14)\end{array}$ & $\begin{array}{l}-0.021 \\
(-0.31)\end{array}$ \\
\hline \multirow[t]{2}{*}{$\mathrm{N}$} & 163 & 161 & 163 & 160 & 157 & 149 & 149 & 151 \\
\hline & -7 & -6 & -5 & -4 & -3 & -2 & -1 & 0 \\
\hline$\alpha_{2}$ & $\begin{array}{l}-0.014 \\
(-0.29)\end{array}$ & $\begin{array}{l}-0.031 \\
(-0.49)\end{array}$ & $\begin{array}{l}0.200 \\
(1.00)\end{array}$ & $\begin{array}{l}0.072 \\
(0.67)\end{array}$ & $\begin{array}{l}0.225 \\
(1.53)\end{array}$ & $\begin{array}{c}0.108^{*} \\
(1.68)\end{array}$ & $\begin{array}{c}0.097^{* *} \\
(1.99)\end{array}$ & $\begin{array}{c}0.101^{* *} \\
(2.18)\end{array}$ \\
\hline \multirow[t]{2}{*}{$\mathrm{N}$} & 149 & 149 & 140 & 139 & 136 & 142 & 141 & 137 \\
\hline & 1 & 2 & 3 & 4 & 5 & 6 & 7 & 8 \\
\hline$\alpha_{2}$ & $\begin{array}{l}0.086 \\
(1.29)\end{array}$ & $\begin{array}{l}0.077 \\
(0.99)\end{array}$ & $\begin{array}{l}-0.158 \\
(-1.30)\end{array}$ & $\begin{array}{l}-0.094 \\
(-0.60)\end{array}$ & $\begin{array}{l}-0.011 \\
(-0.11)\end{array}$ & $\begin{array}{c}-0.159^{*} \\
(-1.67)\end{array}$ & $\begin{array}{l}-0.197 \\
(-1.60)\end{array}$ & $\begin{array}{l}-0.158 \\
(-1.16)\end{array}$ \\
\hline \multirow[t]{2}{*}{$\mathrm{N}$} & 136 & 132 & 131 & 122 & 116 & 118 & 118 & 118 \\
\hline & 9 & 10 & 11 & 12 & 13 & 14 & 15 & \\
\hline$\alpha_{2}$ & $\begin{array}{l}-0.168 \\
(-1.47)\end{array}$ & $\begin{array}{l}-0.148 \\
(-1.37)\end{array}$ & $\begin{array}{l}-0.063 \\
(-0.33)\end{array}$ & $\begin{array}{l}-0.047 \\
(-0.41)\end{array}$ & $\begin{array}{c}0.091 \\
(0.78)\end{array}$ & $\begin{array}{l}0.119 \\
(1.07)\end{array}$ & $\begin{array}{l}0.190 \\
(1.65)\end{array}$ & \\
\hline $\mathrm{N}$ & 118 & 114 & 109 & 103 & 102 & 99 & 93 & \\
\hline
\end{tabular}




\section{Table 8}

\section{Validity Test: Control}

This table presents the RD design validity test for observable control variables using a two-stage least-squares approach with local polynomials of order one. The standard controls are defined in Table 4. Underlying Return is the annualized total return of the underlying. Deviation is defined as the absolute distance between the time to maturity of a structured product and its closest standardized time to maturity $(0.5,1,1.5,2$ or 3 years $)$ in years. We apply optimal bandwidths based on the rule-of-thumb approach. We report the coefficients of discontinuity $\alpha_{2}$ estimated in Eqn. (5). $t$-statistics are reported in parentheses. ${ }^{*},{ }^{* *}$, and ${ }^{* * *}$ denote significance at the $10 \%, 5 \%$, and $1 \%$ level, respectively.

\begin{tabular}{|c|c|c|c|c|}
\hline & IBES Div Yield & Hist Div Yield & Higher Div & Delta \\
\hline$\alpha_{2}$ & $\begin{array}{l}0.011 \\
(0.92)\end{array}$ & $\begin{array}{l}0.050 \\
(1.12)\end{array}$ & $\begin{array}{l}-0.085 \\
(-0.32)\end{array}$ & $\begin{array}{c}0.017^{*} \\
(1.70)\end{array}$ \\
\hline \multirow[t]{2}{*}{$\mathrm{N}$} & 137 & 137 & 137 & 137 \\
\hline & $\begin{array}{c}\text { Average Trading } \\
\text { Size } \\
\end{array}$ & Features & Impl Vola & $\begin{array}{c}\text { Market Cap } \\
\text { Underlying }\end{array}$ \\
\hline$\alpha_{2}$ & $\begin{array}{l}0.181 \\
(0.27)\end{array}$ & $\begin{array}{l}-0.648 \\
(-1.42)\end{array}$ & $\begin{array}{l}-0.062 \\
(-1.12)\end{array}$ & $\begin{array}{l}0.506 \\
(0.93)\end{array}$ \\
\hline \multirow[t]{2}{*}{$\mathrm{N}$} & 99 & 137 & 137 & 137 \\
\hline & $\begin{array}{c}\text { 3m Excess Return } \\
\text { Underlying }\end{array}$ & $\begin{array}{l}12 \mathrm{~m} \text { Excess } \\
\text { Return Underlying }\end{array}$ & $\begin{array}{c}\text { 1m Turnover } \\
\text { Underlying }\end{array}$ & $\begin{array}{c}\text { 3m Turnover } \\
\text { Underlying }\end{array}$ \\
\hline$\alpha_{2}$ & $\begin{array}{l}-0.078 \\
(-1.41)\end{array}$ & $\begin{array}{l}-0.084 \\
(-0.63)\end{array}$ & $\begin{array}{l}0.040 \\
(0.05)\end{array}$ & $\begin{array}{l}-0.006 \\
(-0.01)\end{array}$ \\
\hline \multirow[t]{2}{*}{$\mathrm{N}$} & 137 & 137 & 137 & 137 \\
\hline & $\begin{array}{l}\text { 1m Call Option } \\
\text { Volume }\end{array}$ & $\begin{array}{l}\text { 1m Put Option } \\
\text { Volume }\end{array}$ & Underlying Return & Deviation \\
\hline$\alpha_{2}$ & $\begin{array}{l}0.006 \\
(0.36)\end{array}$ & $\begin{array}{l}0.006 \\
(0.35)\end{array}$ & $\begin{array}{l}-0.035 \\
(-0.19)\end{array}$ & $\begin{array}{l}0.037 \\
(1.01)\end{array}$ \\
\hline $\mathrm{N}$ & 137 & 137 & 137 & 137 \\
\hline
\end{tabular}




\section{Table 9}

\section{Nearest Neighbor Matching}

This table presents results of the Nearest Neighbor matching approach. For each underlying that is actually chosen for a structured product, five non-chosen underlyings that are closest neighbors with respect to the Mahalanobis distance are selected. The matching variables are the index and industry of an underlying, the underlying's market capitalization, the three and twelve months excess returns, the one month and three months cumulated trading volumes as well as the one month call (put) volume written on the underlying. Depending on the specification of the model, the matching variables are lagged by one, two and three weeks. We define Industry as the two-digit SIC code. Higher Vola (Higher Div) is a binary variable that is equal to one if Impl Vola (IBES Dividend Yield) is larger than Hist Vola (Hist Dividend Yield), and zero otherwise. Mean Difference Higher Vola (Mean Difference Higher Div) is calculated as the difference between the value of Higher Vola (Higher Div) of the underlying that is actually chosen and the mean value of Higher Vola (Higher Div) of the matched underlyings. We calculate Impl Vola as the annualized implied volatility of the product's option on the underlying calculated for the lifetime of the product. IBES Div Yield is the ratio between the present value of expected dividend payments based on IBES forecasts that occur during the lifetime of a product and the stock price of the underlying at the initial fixing date. Corresponding Index is the index of the underlying. The standard controls are defined in Table 2 $p$-values of the one-sided $t$-test are reported in parentheses. ${ }^{*},{ }^{* *}$, and ${ }^{* * *}$ denote significance at the $10 \%, 5 \%$, and $1 \%$ level, respectively.

\begin{tabular}{lccc}
\hline & $(1)$ & $(2)$ & $(3)$ \\
\hline \multirow{2}{*}{ Corresponding Index } & Yes & Yes & Yes \\
Industry & Yes & Yes & Yes \\
Market Cap Underlying & Yes & Yes & Yes \\
3m Excess Return Underlying & Yes & Yes & Yes \\
12m Excess Return Underlying & Yes & Yes & Yes \\
1m Turnover Underlying & Yes & Yes & Yes \\
3m Turnover Underlying & Yes & Yes & Yes \\
1m Call Option Volume & Yes & Yes & Yes \\
1m Put Option Volume & Yes & Yes & Yes \\
& \multicolumn{2}{c}{} \\
\hline \multirow{2}{*}{ Lag } & 1 Week & 2 Weeks & 3 Weeks \\
& \multicolumn{3}{c}{} \\
\hline \multirow{2}{*}{ Mean Difference Higher Vola } & $0.023^{* *}$ & $0.020^{*}$ & $0.022^{* *}$ \\
& $(0.04)$ & $(0.06)$ & $(0.05)$ \\
Mean Difference Higher Div & $0.060^{* * *}$ & $0.058^{* * *}$ & $0.062^{* * *}$ \\
& $(0.00)$ & $(0.00)$ & $(0.00)$ \\
\hline \hline
\end{tabular}




\section{Table 10}

\section{Robustness Tests: Volatility Measures}

This table presents various robustness tests for our main findings. The dependent variable is the Issue Premium (IP), which is the issue price of a structured product minus its replication value, scaled by the issue price, expressed in percentage points. Higher Vola is a binary variable that is equal to one if Impl Vola is larger than Hist Vola, and zero otherwise. Implied Volatility Squared is calculated as the square product of Impl Vola. Implied Volatility 182 is the annualized implied volatility of an at-the-money put option on the product's underlying with a maturity of 182 days. HH-Index is defined as the Herfindal-Hirshman-Index calculated based on the market shares of the firms in the number of products on the initial fixing date. We calculate Funding Needs as the quarterly ratio between deposit and total assets. CDS Spread is the CDS Spread of the issuer at the initial fixing date. We use the Economic Barometer published by the KOF Swiss Economic Institute as a proxy for Economic Environment. The standard controls are defined in Table 2, We control for year fixed effects. Depending on the specification of the model, we additionally control for product category, issuer and underlying fixed effects. $t$-statistics are reported in parentheses. ${ }^{*},{ }^{* *}$, and ${ }^{* * *}$ denote significance at the $10 \%, 5 \%$, and $1 \%$ level, respectively.

\begin{tabular}{|c|c|c|c|c|c|c|}
\hline VARIABLES & $\begin{array}{l}(1) \\
\text { IP }\end{array}$ & $\begin{array}{l}(2) \\
\text { IP }\end{array}$ & $\begin{array}{l}(3) \\
\text { IP }\end{array}$ & $\begin{array}{l}(4) \\
\text { IP }\end{array}$ & $\begin{array}{l}5) \\
\text { IP }\end{array}$ & $\begin{array}{l}(6) \\
\text { IP }\end{array}$ \\
\hline Impl Vola & $\begin{array}{c}9.980^{* * *} \\
(9.79)\end{array}$ & $\begin{array}{c}23.525^{* * *} \\
(7.72)\end{array}$ & $\begin{array}{c}12.192^{* * *} \\
(9.46)\end{array}$ & & $\begin{array}{c}12.018^{* * *} \\
(9.28)\end{array}$ & $\begin{array}{c}7.914^{* * *} \\
(3.76)\end{array}$ \\
\hline Hist Vola & $\begin{array}{c}-4.947^{* * * *} \\
(-6.17)\end{array}$ & $\begin{array}{c}-5.022^{* * *} \\
(-5.76)\end{array}$ & $\begin{array}{c}-6.363^{* * *} \\
(-6.90)\end{array}$ & $\begin{array}{l}0.030 \\
(0.04)\end{array}$ & $\begin{array}{c}-5.153^{* * *} \\
(-5.51)\end{array}$ & $\begin{array}{c}-5.861 * * * \\
(-5.01)\end{array}$ \\
\hline Higher Vola & $\begin{array}{c}0.646^{* * * *} \\
(4.31)\end{array}$ & $\begin{array}{c}0.382^{* *} \\
(2.26)\end{array}$ & $\begin{array}{c}0.594^{* * * *} \\
(3.58)\end{array}$ & & $\begin{array}{c}0.764^{* * * *} \\
(3.71)\end{array}$ & $\begin{array}{c}0.427^{*} \\
(1.88)\end{array}$ \\
\hline Implied Volatility Squared & & $\begin{array}{c}-19.159^{* * *} \\
(-5.35)\end{array}$ & & & & \\
\hline VSMI & & & $\begin{array}{c}-0.078^{* * *} \\
(-5.88)\end{array}$ & & & \\
\hline Implied Volatility 182 & & & & $\begin{array}{l}-0.473 \\
(-0.64)\end{array}$ & & \\
\hline Higher Vola 182 & & & & $\begin{array}{c}0.715^{* * * *} \\
(3.85)\end{array}$ & & \\
\hline HH-Index & & & & & $\begin{array}{c}7.406^{* * *} \\
(2.82)\end{array}$ & \\
\hline Funding Needs & & & & & $\begin{array}{l}-1.711 \\
(-0.81)\end{array}$ & \\
\hline CDS Spread & & & & & $\begin{array}{c}-0.705^{* * *} \\
(-3.63)\end{array}$ & \\
\hline Economic Environment & & & & & $\begin{array}{l}0.008 \\
(0.68)\end{array}$ & \\
\hline Market Cap Underlying & $\begin{array}{l}-0.044 \\
(-0.68)\end{array}$ & $\begin{array}{c}0.173^{* *} \\
(2.42)\end{array}$ & $\begin{array}{l}0.090 \\
(1.28)\end{array}$ & $\begin{array}{l}-0.028 \\
(-0.37)\end{array}$ & $\begin{array}{l}0.110 \\
(1.62)\end{array}$ & $\begin{array}{l}0.030 \\
(0.06)\end{array}$ \\
\hline 3m Excess Return Underlying & $\begin{array}{c}1.630^{* * * *} \\
(3.07)\end{array}$ & $\begin{array}{c}1.820^{* * *} \\
(3.05)\end{array}$ & $\begin{array}{c}1.647^{* * * *} \\
(2.77)\end{array}$ & $\begin{array}{l}1.227^{*} \\
(1.88)\end{array}$ & $\begin{array}{c}1.676^{* * * *} \\
(2.77)\end{array}$ & $\begin{array}{l}1.068 \\
(1.02)\end{array}$ \\
\hline 12m Excess Return Underlying & $\begin{array}{l}-0.444 \\
(-1.61)\end{array}$ & $\begin{array}{c}-1.242^{* * * *} \\
(-3.72)\end{array}$ & $\begin{array}{c}-0.577^{*} \\
(-1.88)\end{array}$ & $\begin{array}{c}-0.783^{* *} \\
(-2.37)\end{array}$ & $\begin{array}{c}-0.696^{* *} \\
(-2.20)\end{array}$ & $\begin{array}{l}-0.602 \\
(-1.25)\end{array}$ \\
\hline 1m Turnover Underlying & $\begin{array}{l}-0.124 \\
(-0.49)\end{array}$ & $\begin{array}{l}-0.150 \\
(-0.54)\end{array}$ & $\begin{array}{l}-0.046 \\
(-0.17)\end{array}$ & $\begin{array}{c}0.093 \\
(0.32)\end{array}$ & $\begin{array}{l}-0.035 \\
(-0.13)\end{array}$ & $\begin{array}{l}-0.198 \\
(-0.56)\end{array}$ \\
\hline 3m Turnover Underlying & $\begin{array}{l}0.124 \\
(0.49)\end{array}$ & $\begin{array}{l}0.144 \\
(0.51)\end{array}$ & $\begin{array}{l}0.061 \\
(0.22)\end{array}$ & $\begin{array}{l}-0.111 \\
(-0.37)\end{array}$ & $\begin{array}{l}0.022 \\
(0.08)\end{array}$ & $\begin{array}{l}0.145 \\
(0.30)\end{array}$ \\
\hline 1m CallOptionVolume & $\begin{array}{l}-0.202 \\
(-0.07)\end{array}$ & $\begin{array}{l}1.490 \\
(0.46)\end{array}$ & $\begin{array}{l}-1.239 \\
(-0.38)\end{array}$ & $\begin{array}{l}1.779 \\
(0.51)\end{array}$ & $\begin{array}{c}-7.036^{*} \\
(-1.66)\end{array}$ & $\begin{array}{l}2.500 \\
(1.31)\end{array}$ \\
\hline 1m PutOptionVolume & $\begin{array}{l}-1.429 \\
(-0.43)\end{array}$ & $\begin{array}{l}0.920 \\
(0.25)\end{array}$ & $\begin{array}{l}4.533 \\
(1.24)\end{array}$ & $\begin{array}{l}1.309 \\
(0.34)\end{array}$ & $\begin{array}{l}4.079 \\
(0.91)\end{array}$ & $\begin{array}{l}1.209 \\
(0.24)\end{array}$ \\
\hline Constant & $\begin{array}{l}0.180 \\
(0.28)\end{array}$ & $\begin{array}{c}-2.917^{* * *} \\
(-4.33)\end{array}$ & $\begin{array}{l}-0.312 \\
(-0.59)\end{array}$ & $\begin{array}{c}0.946^{*} \\
(1.79)\end{array}$ & $\begin{array}{c}-2.905^{* *} \\
(-2.04)\end{array}$ & $\begin{array}{l}1.957 \\
(0.80)\end{array}$ \\
\hline Year fixed effects & Yes & Yes & Yes & Yes & Yes & Yes \\
\hline Product Category fixed effects & Yes & No & No & No & No & No \\
\hline Issuer fixed effects & Yes & No & No & No & No & No \\
\hline Underlying fixed effects & No & No & No & No & No & Yes \\
\hline Observations & 1,012 & 1,012 & 1,012 & 994 & 857 & 1,012 \\
\hline R-squared & 0.384 & 0.210 & 0.202 & 0.114 & 0.236 & 0.310 \\
\hline
\end{tabular}




\section{Table 11}

\section{Robustness Tests: Dividend Measures}

This table presents various robustness tests for our main findings. The dependent variable is the Issue Premium (IP), which is the issue price of a structured product minus its replication value, scaled by the issue price, expressed in percentage points. Higher Div is a binary variable that is equal to one if IBES Dividend Yield is larger than Hist Dividend Yield, and zero otherwise. IBES Div Yield Squared is calculated as the square product of IBES Dividend Yield. HH-Index is the Herfindal-Hirshman-Index calculated based on the market shares of the firms in the number of products on the initial fixing date. We calculate Funding Needs as the quarterly ratio between deposit and total assets. CDS Spread is the CDS Spread of the issuer at the initial fixing date. We use the Economic Barometer published by the KOF Swiss Economic Institute as a proxy for Economic Environment. The standard controls are defined in Table 2. We control for year fixed effects. Depending on the specification of the model, we additionally control for product category, issuer and underlying fixed effects. $t$-statistics are reported in parentheses. ${ }^{*},{ }^{* *}$, and ${ }^{* * *}$ denote significance at the $10 \%, 5 \%$, and $1 \%$ level, respectively.

\begin{tabular}{|c|c|c|c|c|}
\hline VARIABLES & $\begin{array}{l}(1) \\
\text { IP }\end{array}$ & $\begin{array}{l}(2) \\
\text { IP }\end{array}$ & $\begin{array}{l}\text { (3) } \\
\text { IP }\end{array}$ & $\begin{array}{l}\text { (4) } \\
\text { IP }\end{array}$ \\
\hline Impl Vola & $\begin{array}{c}6.611^{* * *} \\
(8.90)\end{array}$ & $\begin{array}{c}6.034^{* * *} \\
(7.69)\end{array}$ & $\begin{array}{c}8.136^{* * *} \\
(9.34)\end{array}$ & $\begin{array}{c}7.155^{* * *} \\
(4.57)\end{array}$ \\
\hline IBES Div Yield & $\begin{array}{l}0.167 \\
(0.05)\end{array}$ & $\begin{array}{c}0.892 \\
(0.10)\end{array}$ & $\begin{array}{l}2.627 \\
(0.70)\end{array}$ & $\begin{array}{c}9.840 \\
(1.63)\end{array}$ \\
\hline Hist Div Yield & $\begin{array}{l}-1.109 \\
(-1.08)\end{array}$ & $\begin{array}{c}-2.830^{* *} \\
(-2.57)\end{array}$ & $\begin{array}{c}-2.182^{* *} \\
(-2.09)\end{array}$ & $\begin{array}{c}-2.647^{* *} \\
(-3.02)\end{array}$ \\
\hline Higher Div & $\begin{array}{c}0.285^{*} \\
(1.89)\end{array}$ & $\begin{array}{c}0.628^{* * *} \\
(3.68)\end{array}$ & $\begin{array}{c}0.406^{* *} \\
(2.54)\end{array}$ & $\begin{array}{c}0.612^{* * *} \\
(2.93)\end{array}$ \\
\hline IBES Div Yield Squared & & $\begin{array}{c}27.490 \\
(0.25)\end{array}$ & & \\
\hline HH-Index & & & $\begin{array}{l}3.659 \\
(1.33)\end{array}$ & \\
\hline Funding Needs & & & $\begin{array}{l}-3.045 \\
(-1.38)\end{array}$ & \\
\hline CDS Spread & & & $\begin{array}{c}-0.598 * * * \\
(-2.93)\end{array}$ & \\
\hline Economic Environment & & & $\begin{array}{l}-0.005 \\
(-0.41)\end{array}$ & \\
\hline Market Cap Underlying & $\begin{array}{l}0.027 \\
(0.39)\end{array}$ & $\begin{array}{l}0.106 \\
(1.42)\end{array}$ & $\begin{array}{c}0.143^{* *} \\
(1.99)\end{array}$ & $\begin{array}{l}0.704 \\
(1.19)\end{array}$ \\
\hline 3m Excess Return Underlying & $\begin{array}{l}0.828 \\
(1.50)\end{array}$ & $\begin{array}{l}0.684 \\
(1.12)\end{array}$ & $\begin{array}{c}0.806 \\
(1.28)\end{array}$ & $\begin{array}{c}0.096 \\
(0.10)\end{array}$ \\
\hline 12m Excess Return Underlying & $\begin{array}{l}-0.374 \\
(-1.27)\end{array}$ & $\begin{array}{l}-0.461 \\
(-1.43)\end{array}$ & $\begin{array}{l}-0.412 \\
(-1.25)\end{array}$ & $\begin{array}{l}-0.498 \\
(-1.31)\end{array}$ \\
\hline 1m Turnover Underlying & $\begin{array}{l}0.199 \\
(0.77)\end{array}$ & $\begin{array}{l}0.211 \\
(0.75)\end{array}$ & $\begin{array}{l}0.387 \\
(1.33)\end{array}$ & $\begin{array}{l}0.200 \\
0.57)\end{array}$ \\
\hline $3 \mathrm{~m}$ Turnover Underlying & $\begin{array}{l}-0.218 \\
(-0.83)\end{array}$ & $\begin{array}{l}-0.230 \\
(-0.81)\end{array}$ & $\begin{array}{l}-0.408 \\
(-1.40)\end{array}$ & $\begin{array}{l}-0.350 \\
(-0.70)\end{array}$ \\
\hline 1m CallOptionVolume & $\begin{array}{l}-2.429 \\
(-0.79)\end{array}$ & $\begin{array}{l}-0.556 \\
(-0.17)\end{array}$ & $\begin{array}{c}-9.334^{* *} \\
(-2.10)\end{array}$ & $\begin{array}{c}1.866 \\
(0.83)\end{array}$ \\
\hline 1m PutOptionVolume & $\begin{array}{l}-0.106 \\
(-0.03)\end{array}$ & $\begin{array}{l}1.574 \\
(0.41)\end{array}$ & $\begin{array}{l}5.097 \\
(1.09)\end{array}$ & $\begin{array}{l}5.013 \\
(0.97)\end{array}$ \\
\hline Constant & $\begin{array}{l}0.561 \\
(0.84)\end{array}$ & $\begin{array}{l}-0.487 \\
(-0.92)\end{array}$ & $\begin{array}{l}0.057 \\
(0.04)\end{array}$ & $\begin{array}{l}0.376 \\
(0.14)\end{array}$ \\
\hline Year fixed effects & Yes & Yes & Yes & Yes \\
\hline Product Category fixed effects & Yes & No & No & No \\
\hline Issuer fixed effects & Yes & No & No & No \\
\hline Underlying fixed effects & No & No & No & Yes \\
\hline Observations & 1,012 & 1,012 & 857 & 1,012 \\
\hline R-squared & 0.325 & 0.166 & 0.161 & 0.294 \\
\hline
\end{tabular}




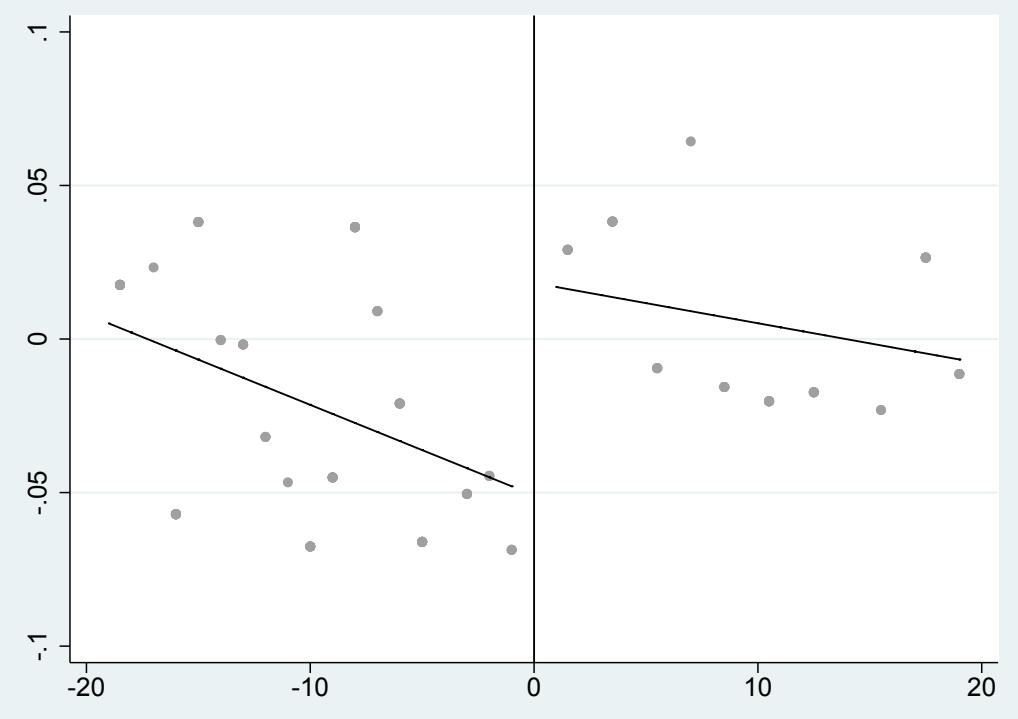

(a) Binwidth $=5$

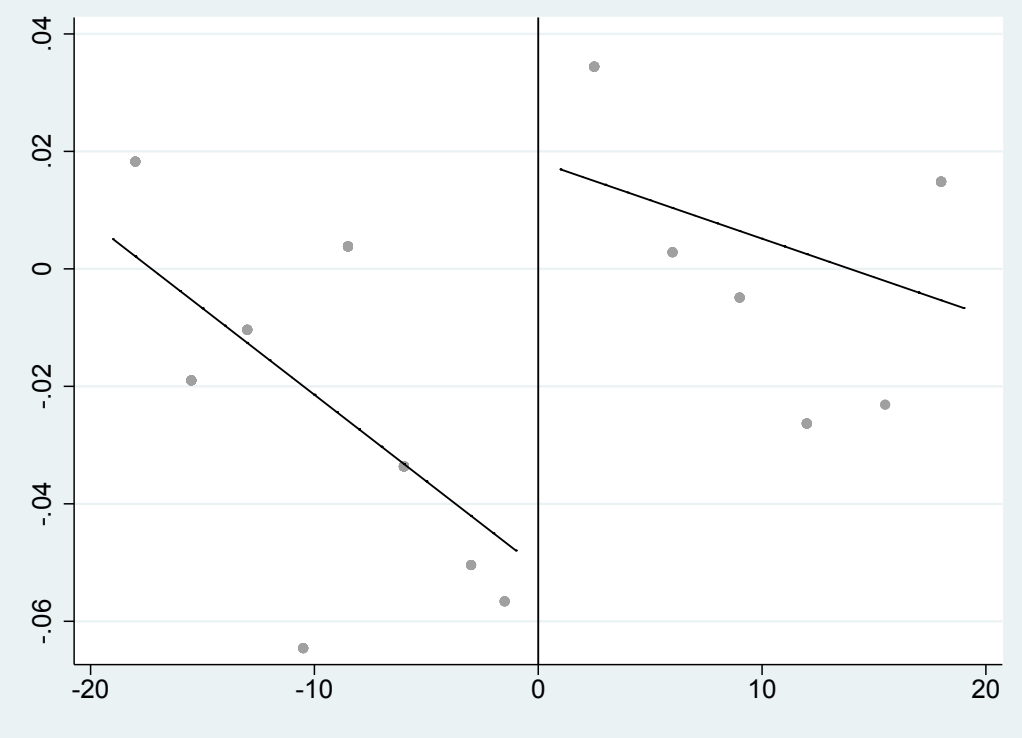

(b) Binwidth $=10$

Figure 1

\section{Unexplained Performance}

This figure shows the distribution of the unexplained performance (UP) in a time window of [-19, 19] days around the maturity date. The projected dividend payment date is defined as the difference between the expected ex-dividend date and the maturity date in days. A negative (positive) value indicates that the ex-dividend date is expected to occur before (after) the maturity date. UP is calculated as the residual of regression Eqn. (3). We fit a linear function on either side of the threshold using binwidths of 5 and 10. Each bin represents the average of either 5 or 10 observations. 
Figure 2

Product Issuances throughout the Year

This figure depicts the number of products issued per month. Month number 1 is January, number 2 is February and so forth.

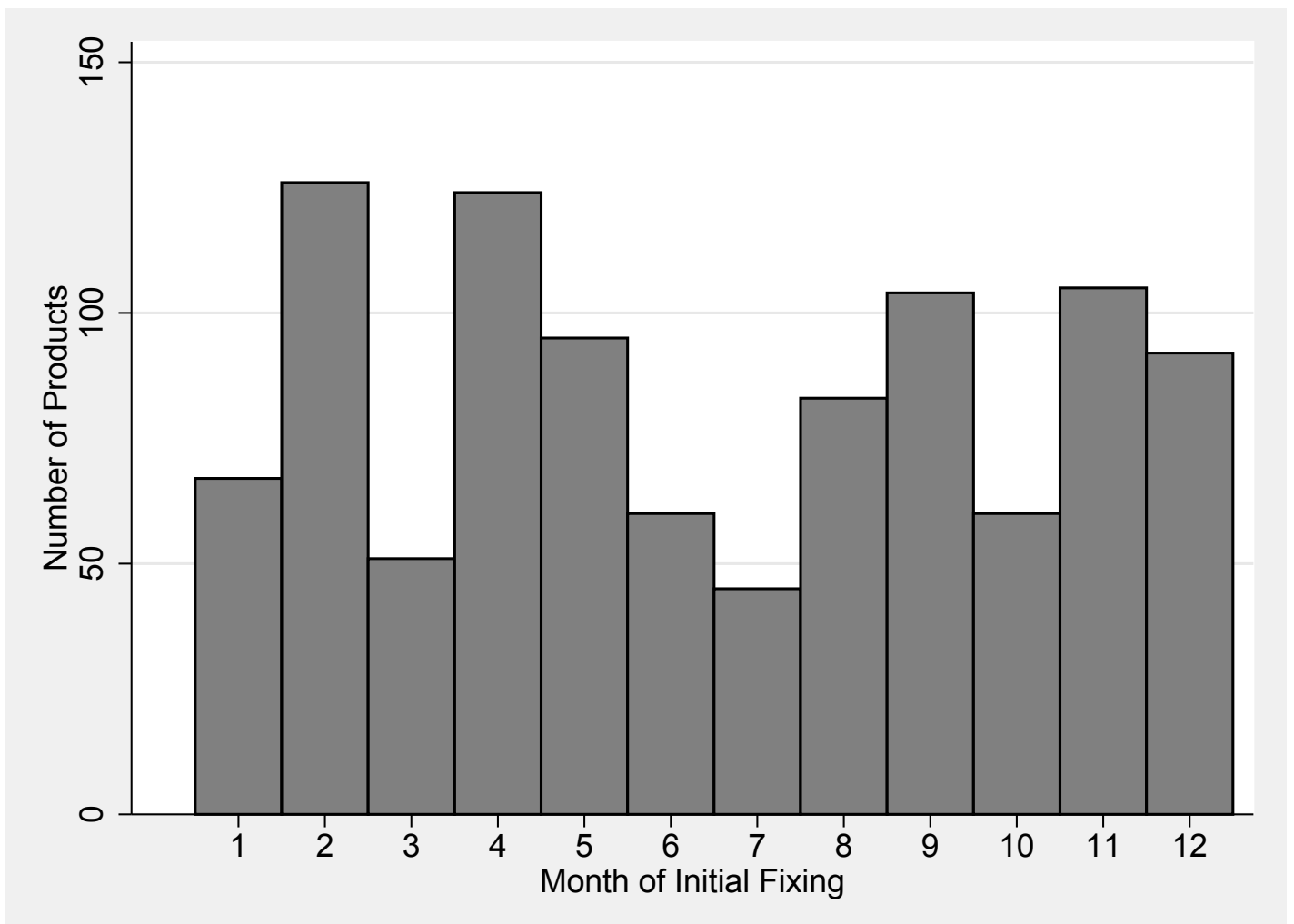


Figure 3

\section{Time to Maturity}

This figure shows the distribution of time to maturity in a time window of $[-19,19]$ days around the maturity date. The projected dividend payment date is defined as the difference between the expected ex-dividend date and the maturity date in days. A negative (positive) value indicates that the ex-dividend date is expected to occur before (after) the maturity date. The time of maturity is calculated in years. Solid dots indicate products with a time to maturity of one year or shorter and hollow dots products with a time to maturity of longer than one year.

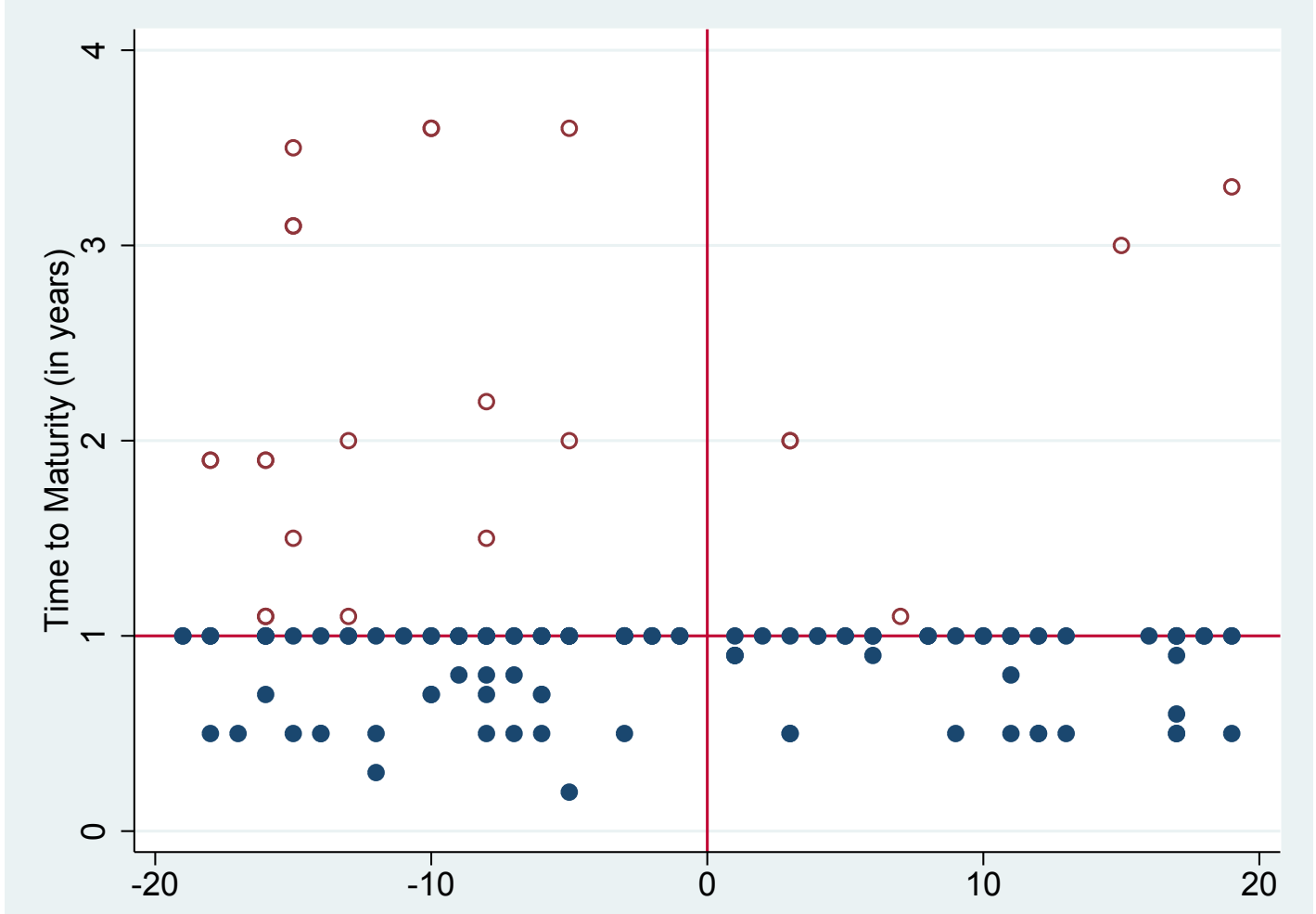

